\title{
Psychological Interpretation, Based On Statistical Analysis of Impact of Music on Rural and Urban People When Their Music Inclination Collides With Personality and Vice Versa: Comparative Study
}

\author{
Dr. Shveata Misra $^{1}{ }^{*}$, Prof. Ina Shastri ${ }^{2}$
}

\section{ABSTRACT}

Music has a sorcerous impact on people unbiased of caste religion and greed. Impact of music on people is so cryptical that individual does not realize that what impact music is casting or spelling on them while they are listening. This way music even affects the personality and behavior of the listener. The music people of urban and rural community hear as per their music inclination also castes impact on their personality and behavior. The following research paper outlines and show the comparative study of how the music inclination of Urban and rural people affects the personality according to their music preferences and what music certain personality of Urban and Rural people prefers.

Keywords: Analytical, Comparative, Inclination, Music, People, Personality, Rural, Urban

\section{METHODS}

Using the purposive sampling procedure, the total number of sample taken for the age group 13 19 years, 20 - 40 years and 40+ - 75+ years were 1000. 13 - 19 years of youth were from the classes $8^{\text {th }}$ to graduation level. It includes the students from the schools and universities of Lucknow, Kanpur and Rajasthan. 20 - 40 years of people were from the post graduation level including the working people from the field of engineering, doctors, bankers etc. 40+ - $75+$ years of people were engaged into different jobs, business or were even retired people and also few were from the old age homes as well.

Under the age group of 13 - 19 years out of 1000, total 946 appeared for the test. Amongst them total number males were 483 and that of females where 463 and rest 54 were not present. Each 100 students were taken from all the classes including both males and females on equal ration i.e.

\footnotetext{
${ }^{1}$ Ph.D Music, Department of Music, Banasthali University, Rajasthan, India

${ }^{2}$ Research Supervisor and Head of Department of Music, Banasthali University, Rajasthan, India

*Responding Author

(C) 2016 I S Misra, I Shastri; licensee IJIP. This is an Open Access Research distributed under the terms of the Creative Commons Attribution License (http://creativecommons.org/licenses/by/2.0), which permits unrestricted use, distribution, and reproduction in any Medium, provided the original work is properly cited.
} 
50 males and 50 females. Few of them amongst the participants were learning music, many of them just had interest in listening to different types of music, and few even had no inclination towards music and also many were from different subjects like commerce, science, sports and arts as well. Therefore this sampling is supposed to be the purposive sampling.

Under the age group of 20 - 40 years out of 1000 total 946 appeared for the test. Amongst them total number of males were 463 and that of females where 483 and rest 54 were not present. We took equal numbers of males and females for this age group.

Under the age group of 40+ - 75+ years out of 1000 total 900 appeared for the test. Amongst them total number males were 468 and that of females where 432 and rest 100 were not present. We took 100 - 100 employed professors, lecturers, who teaches post graduation level i.e. 100 from pg first year and 100 from pg second year total 200 students and 200 subjects who were not employed or employed but had resigned due to certain reasons and circumstances. 300 people were from the different jobs including that of bankers doctors teachers (both related to music and non music), IAS officers policemen etc. And 200 other were the people who were either living in old age homes or are single in their old age or are forced to live isolate, lonely.

\section{Objective:}

To compare average score obtained by rural and urban people according to their personality traits and music inclinations for various age groups.

To find the answers for the above planned aims every single students, adults and seniors, were given the sets of questionnaire to answer. To get the personality of each, they were given 'TEN ITEAM PERSONALITY LIST' and next to know their favorite music style or genres they have been given the 'SHORT MUSIC PREFERENCE LIST'.

Further data have been elaborated with graphical presentation for more lucid view of the analysis for the broad picture of acceptance of our hypothesis. The purpose of graphical presentation of data is to give a visual of the numbers by using various charts or bar diagram.

On getting the entire solved questionnaire, we used statistical process using SPSS - 16.0 where we used Chi-Square $-\left[\mathbf{x}^{2}{ }_{\mathbf{e}}=\sum\left(\mathbf{O}_{\mathbf{i}}-\mathbf{E}_{\mathbf{i}}\right)^{\mathbf{2}} / \mathbf{E}_{\mathbf{i}}\right]$ to see the association between personality and music types including the gender criteria as $5 \%$ level of significance. This has been used for statistical hypothesis. It's been used to compare observed data with data we would expect to obtain according to a specific hypothesis.

Now after finishing with the above mentioned statistical process and analysis we would further proceed with our other two statistical processes i.e. - $t$ - Test and ANOVA for the result and conclusion for our hypothesis, i.e. - 
Psychological Interpretation, Based On Statistical Analysis of Impact of Music on Rural and Urban People When Their Music Inclination Collides With Personality and Vice Versa - Comparative Study

* To compare average score obtained by rural and urban people according to their personality traits and music inclinations for various age groups.

Above mentioned objective and methods would remain the same for the analysis between the rest of the age groups i.e. 13 - 19years, 20 - 40 years and 40+ - 75+ years. Each analysis would be explained individually through tabulation form.

\section{t - TEST ANALYSIS FOR RURAL \& URBAN PERSONALITY: 13 - 19 YEARS}

$\mathrm{T}$ - Test is applied to check the significant difference in the average score obtained for the rural and urban people for the different personality traits by applying Simple Random Analysis.

\section{A. Openness:}

Ho1: The average scores obtained by rural and urban community are equal for Openness personality.

H1: The averages are not equal for Openness personality.

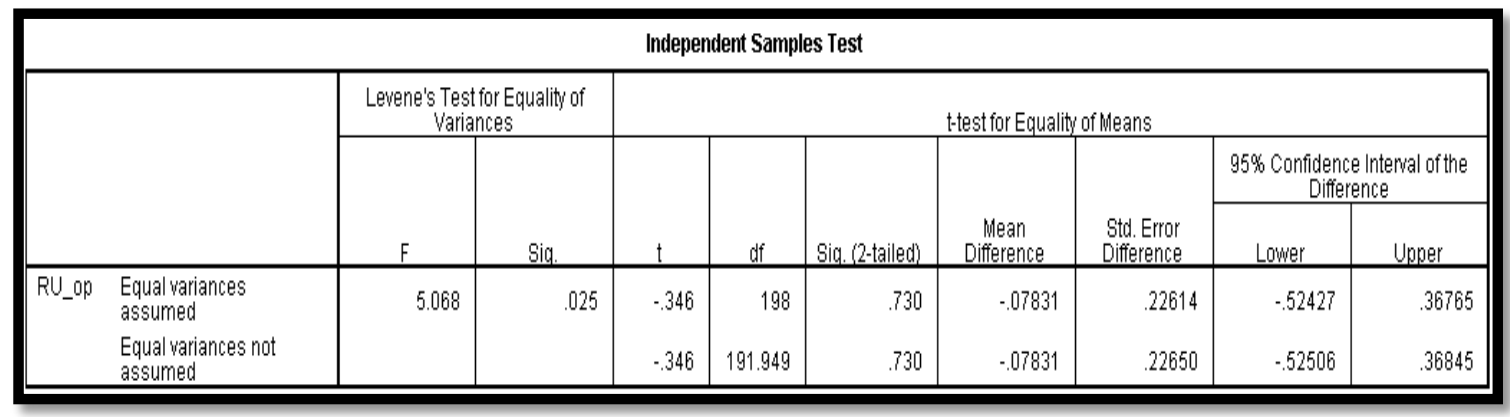

(B)-Fig.1

In this analysis there is an insignificant difference among the people from Rural and Urban community with Personality trait of Openness as the ' $P$ ' value is greater than 0.05 .

\section{B. Agreeableness:}

Ho2: The average scores obtained by rural and urban community are equal for Agreeableness personality.

H2: The averages are not equal for Agreeableness personality.

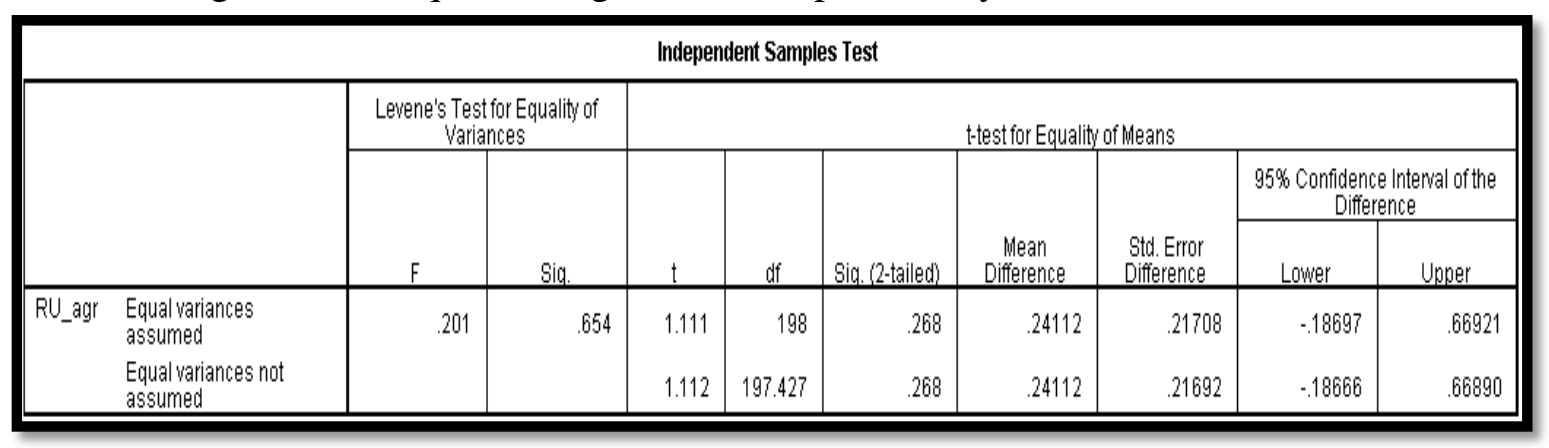

(B)-Fig.2

In this analysis there is insignificant difference among the people from Rural and Urban community with Personality trait of Agreeableness as the ' $P$ ' value is greater than 0.05 . 
Psychological Interpretation, Based On Statistical Analysis of Impact of Music on Rural and Urban People When Their Music Inclination Collides With Personality and Vice Versa - Comparative Study

\section{Consciousness:}

Ho3: The average scores obtained by rural and urban community are equal for Consciousness personality.

H3: The averages are not equal for Consciousness personality.

\begin{tabular}{|c|c|c|c|c|c|c|c|c|c|c|}
\hline \multicolumn{11}{|c|}{ Independent Samples Test } \\
\hline & & \multicolumn{2}{|c|}{$\begin{array}{l}\text { Levene's Test for Equality of } \\
\text { Variances }\end{array}$} & \multicolumn{7}{|c|}{ t-test for Equality of Means } \\
\hline & & \multirow[b]{2}{*}{$F$} & \multirow[b]{2}{*}{ Siq. } & \multirow[b]{2}{*}{$t$} & \multirow[b]{2}{*}{ df } & \multirow[b]{2}{*}{ Sia. (2-tailed) } & \multirow[b]{2}{*}{$\begin{array}{c}\text { Mean } \\
\text { Difierence } \\
\end{array}$} & \multirow[b]{2}{*}{$\begin{array}{l}\text { Std. Error } \\
\text { Difference }\end{array}$} & \multicolumn{2}{|c|}{$\begin{array}{l}95 \% \text { Confidence Interval of the } \\
\text { Difierence }\end{array}$} \\
\hline & & & & & & & & & Lower & Upper \\
\hline RU_con & $\begin{array}{l}\text { Equal variances } \\
\text { assumed }\end{array}$ & 4.948 & .027 & 7.370 & 198 & .000 & 1.35844 & .18432 & .99496 & 1.72191 \\
\hline & $\begin{array}{l}\text { Equal variances not } \\
\text { assumed }\end{array}$ & & & 7.352 & 185.458 & .000 & 1.35844 & .18476 & .99393 & 1.72294 \\
\hline
\end{tabular}

(B)-Fig.3

In this analysis there is a significant difference among the people from Rural and Urban community with Personality trait of Consciousness as the 'P' value is lesser than 0.05 .

\section{Extraversion:}

Ho4: The average scores obtained by rural and urban community are equal for Extraversion personality.

H4: The averages are not equal for Extraversion personality.

\begin{tabular}{|c|c|c|c|c|c|c|c|c|c|c|}
\hline \multicolumn{11}{|c|}{ Independent Samples Test } \\
\hline & & \multicolumn{2}{|c|}{$\begin{array}{c}\text { Levene's Test for Equality of } \\
\text { Variances }\end{array}$} & \multicolumn{7}{|c|}{ t-test for Equality of Means } \\
\hline & & \multirow[b]{2}{*}{$\mathrm{F}$} & \multirow[b]{2}{*}{ Sig. } & \multirow[b]{2}{*}{$t$} & \multirow[b]{2}{*}{ df } & \multirow[b]{2}{*}{ Sig. (2-tailed) } & \multirow[b]{2}{*}{$\begin{array}{c}\text { Mean } \\
\text { Difference }\end{array}$} & \multirow[b]{2}{*}{$\begin{array}{l}\text { Std. Error } \\
\text { Difference }\end{array}$} & \multicolumn{2}{|c|}{$\begin{array}{l}95 \% \text { Confidence Interval of the } \\
\text { Difference }\end{array}$} \\
\hline & & & & & & & & & Lower & Upper \\
\hline RU_ext & $\begin{array}{l}\text { Equal variances } \\
\text { assumed }\end{array}$ & .754 & .386 & 12.687 & 198 & .000 & 3.08741 & .24336 & 2.60751 & 3.56731 \\
\hline & $\begin{array}{l}\text { Equal variances not } \\
\text { assumed }\end{array}$ & & & 12.692 & 197.910 & .000 & 3.08741 & .24325 & 2.60771 & 3.56711 \\
\hline
\end{tabular}

(B)-Fig. 4

In this analysis there is a significant difference among the people from Rural and Urban community with Personality trait of Extraversion as the 'P' value is lesser than 0 05 .

\section{E. Neuroticism:}

Ho5: The average scores obtained by rural and urban community are equal for Neuroticism personality.

H5: The averages are not equal for Neuroticism personality. 
Psychological Interpretation, Based On Statistical Analysis of Impact of Music on Rural and Urban People When Their Music Inclination Collides With Personality and Vice Versa - Comparative Study

\begin{tabular}{|c|c|c|c|c|c|c|c|c|c|c|}
\hline \multicolumn{11}{|c|}{ Independent Samples Test } \\
\hline & & \multicolumn{2}{|c|}{$\begin{array}{c}\text { Levene's Test for Equality of } \\
\text { Variances }\end{array}$} & \multicolumn{7}{|c|}{ t-test for Equality of Means } \\
\hline & & \multirow[b]{2}{*}{$F$} & \multirow[b]{2}{*}{ Silg. } & \multirow[b]{2}{*}{$t$} & \multirow[b]{2}{*}{$d f$} & \multirow[b]{2}{*}{ Sig. (2-tailed) } & \multirow[b]{2}{*}{$\begin{array}{c}\text { Mean } \\
\text { Difference }\end{array}$} & \multirow[b]{2}{*}{$\begin{array}{l}\text { Std. Error } \\
\text { Difference }\end{array}$} & \multicolumn{2}{|c|}{$\begin{array}{l}95 \% \text { Confidence Interval of the } \\
\text { Difierence }\end{array}$} \\
\hline & & & & & & & & & Lower & Upper \\
\hline RU_neu & $\begin{array}{l}\text { Equal variances } \\
\text { assumed }\end{array}$ & 2.575 & .110 & -2.497 & 198 & .013 & .55616 & .22270 & .99532 & -11699 \\
\hline & $\begin{array}{l}\text { Equal variances not } \\
\text { assumed }\end{array}$ & & & -2.494 & 192.911 & .013 & .55616 & .22302 & .99602 & -11629 \\
\hline
\end{tabular}

(B)-Fig.5

In this analysis there is a significant difference among the people from Rural and Urban community with Personality trait of Neuroticism as the ' $P$ ' value is lesser than 0.05 .

\section{CONCLUSION}

For tables A and B, we could conclude that there is no significant difference in average scores of rural and urban people for two personality traits i.e. - Openness and Agreeableness.

For rest, there is significant difference between the two that could be noticed from tables C, D and E i.e. - Consciousness, Extraversion, \& Neuroticism.

\section{t - TEST ANALYSIS FOR RURAL \& URBAN ON MUSIC TYPES: 13 - 19 YEARS \\ a) Classical Music:}

Ho1: The average scores obtained by rural and urban community are equal for Classical Music type.

H1: The averages are not equal for Classical Music type.

\begin{tabular}{|c|c|c|c|c|c|c|c|c|c|c|}
\hline \multicolumn{11}{|c|}{ Independent Samples Test } \\
\hline & & \multicolumn{2}{|c|}{$\begin{array}{c}\text { Levene's Test for Equality of } \\
\text { Variances }\end{array}$} & \multicolumn{7}{|c|}{ t-test for Equality of Means } \\
\hline & & \multirow[b]{2}{*}{$F$} & \multirow[b]{2}{*}{ Sig. } & \multirow[b]{2}{*}{$t$} & \multirow[b]{2}{*}{ df } & \multirow[b]{2}{*}{ Sia. (2-tailed) } & \multirow[b]{2}{*}{$\begin{array}{l}\text { Mean } \\
\text { Difference }\end{array}$} & \multirow[b]{2}{*}{$\begin{array}{l}\text { Std. Error } \\
\text { Difference }\end{array}$} & \multicolumn{2}{|c|}{$\begin{array}{l}95 \% \text { Confidence Interval of the } \\
\text { Difference }\end{array}$} \\
\hline & & & & & & & & & Lower & Upper \\
\hline RU_dls & $\begin{array}{l}\text { Equal variances } \\
\text { assumed }\end{array}$ & 40.356 & .000 & -3.613 & 150 & .000 & -1.20734 & .33416 & -1.86760 & .54708 \\
\hline & $\begin{array}{l}\text { Equal variances not } \\
\text { assumed }\end{array}$ & & & -3.146 & 71.477 & .002 & -1.20734 & .38382 & -1.97256 &. .44212 \\
\hline
\end{tabular}

(B)-Fig.6

In this analysis there is a significant difference among the people from Rural and Urban community with inclination towards Classical Music Type as the 'P' value is lesser than 0 .05. b) Folk:

Ho2: The average scores obtained by rural and urban community are equal for Folk music type.

H2: The averages are not equal for Folk music type. 
Psychological Interpretation, Based On Statistical Analysis of Impact of Music on Rural and Urban People When Their Music Inclination Collides With Personality and Vice Versa - Comparative Study

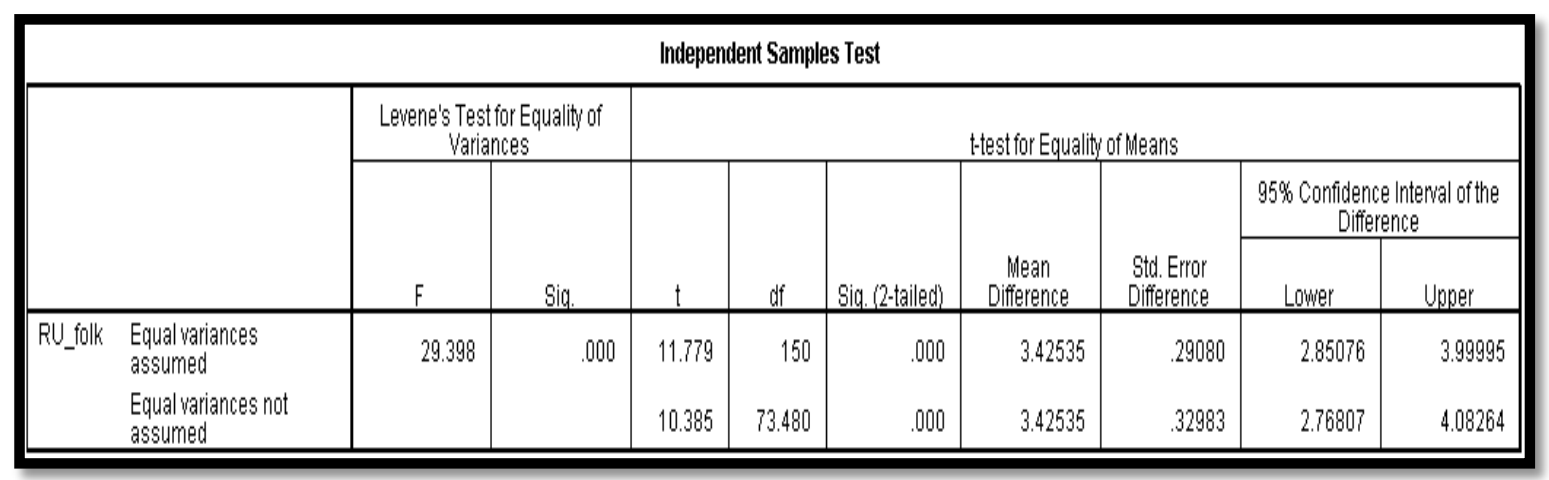

(B)-Fig.7

In this analysis there is a significant difference among the people from Rural and Urban community with inclination towards Folk Music Type as the ' $P$ ' value is lesser than 0.05.

c) Rap/Rock/Hip-hop:

Ho3: The average scores obtained by rural and urban community are equal for Rap/Rock/HipHop Music Type.

H3: The averages are not equal for Rap/Rock/Hip-Hop Music Type.

\begin{tabular}{|c|c|c|c|c|c|c|c|c|c|c|}
\hline \multicolumn{11}{|c|}{ Independent Samples Test } \\
\hline & & \multicolumn{2}{|c|}{$\begin{array}{c}\text { Levene's Test for Equality of } \\
\text { Variances }\end{array}$} & \multicolumn{7}{|c|}{ t-test for Equality of Means } \\
\hline & & \multirow[b]{2}{*}{$F$} & \multirow[b]{2}{*}{ Sig. } & \multirow[b]{2}{*}{$t$} & \multirow[b]{2}{*}{$d f$} & \multirow[b]{2}{*}{ Sia. (2-tailed) } & \multirow[b]{2}{*}{$\begin{array}{c}\text { Mean } \\
\text { Difference }\end{array}$} & \multirow[b]{2}{*}{$\begin{array}{l}\text { Stdd. Error } \\
\text { Difference }\end{array}$} & \multicolumn{2}{|c|}{$\begin{array}{l}95 \% \text { Confidence Interval of the } \\
\text { Difference }\end{array}$} \\
\hline & & & & & & & & & Lower & Upper \\
\hline RU_rapHi & $\begin{array}{l}\text { Equal variances } \\
\text { assumed }\end{array}$ & 2.055 & .157 & -.587 & 56 & .560 & -.44874 & .76510 & -1.98142 & 1.08394 \\
\hline & $\begin{array}{l}\text { Equal variances not } \\
\text { assumed }\end{array}$ & & & .514 & 13.250 & .615 & -.44874 & .87241 & -2.32987 & 1.43238 \\
\hline
\end{tabular}

(B)-Fig.8

In this analysis there is a no significant difference among the people from Rural and Urban community with inclination towards Rap/Rock/Hip-Hop Music Type as the 'P' value is greater than 0.05 .

\section{d) Religious:}

Ho4: The average scores obtained by rural and urban community are equal for Religious Music type.

H4: The averages are not equal for Religious Music Type.

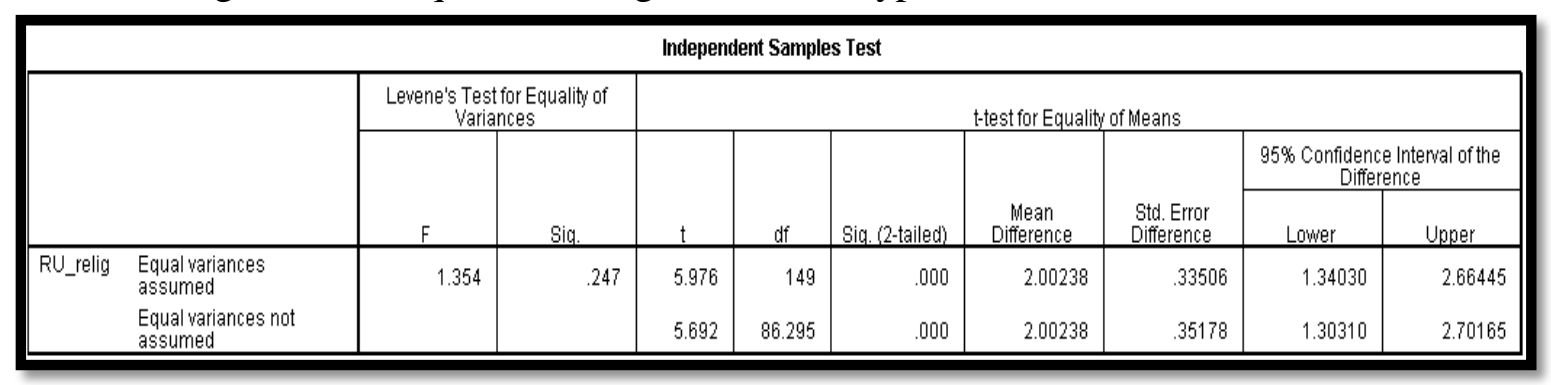

(B)-Fig.9 
Psychological Interpretation, Based On Statistical Analysis of Impact of Music on Rural and Urban People When Their Music Inclination Collides With Personality and Vice Versa - Comparative Study

In this analysis there is a significant difference among the people from Rural and Urban community with inclination towards Religious Music Type as the 'P' value is lesser than 0.05.

e) Bollywood:

Ho5: The average scores obtained by rural and urban community are equal for Bollywood Music Type.

H5: The averages are not equal for Bollywood Music Type.

\begin{tabular}{|c|c|c|c|c|c|c|c|c|c|c|}
\hline \multicolumn{11}{|c|}{ Independent Samples Test } \\
\hline & & \multicolumn{2}{|c|}{$\begin{array}{l}\text { Levene's Test for Equality of } \\
\text { Variances }\end{array}$} & \multicolumn{7}{|c|}{ t-test for Equality of Means } \\
\hline & & \multirow[b]{2}{*}{$\mathrm{F}$} & \multirow[b]{2}{*}{ Sig. } & \multirow[b]{2}{*}{$t$} & \multirow[b]{2}{*}{$\mathrm{df}$} & \multirow[b]{2}{*}{ Sig. (2-tailed) } & \multirow[b]{2}{*}{$\begin{array}{c}\text { Mean } \\
\text { Difference }\end{array}$} & \multirow[b]{2}{*}{$\begin{array}{l}\text { Std. Error } \\
\text { Difference }\end{array}$} & \multicolumn{2}{|c|}{$\begin{array}{l}95 \% \text { Confidence Interval of the } \\
\text { Difierence }\end{array}$} \\
\hline & & & & & & & & & Lower & Upper \\
\hline RU_Bolly & $\begin{array}{l}\text { Equal variances } \\
\text { assumed }\end{array}$ & 3.773 & .054 & .956 & 150 & .341 & -08911 & .09325 & -.27335 & .09514 \\
\hline & $\begin{array}{l}\text { Equal variances not } \\
\text { assumed }\end{array}$ & & & -1.347 & 100.000 & .181 & -08911 & .06615 & -22035 & .04213 \\
\hline
\end{tabular}

(B)-Fig.10

In this analysis there is a no significant difference among the people from Rural and Urban community with inclination towards Bollywood Music Type as the ' $P$ ' value is greater than 0.05

f) Semi-Classical:

Ho6: The average scores obtained by rural and urban community are equal for Semi-Classical Music Type.

H6: The averages are not equal for Semi-Classical Music Type.

\begin{tabular}{|c|c|c|c|c|c|c|c|c|c|c|}
\hline \multicolumn{11}{|c|}{ Independent Samples Test } \\
\hline & & \multicolumn{2}{|c|}{$\begin{array}{c}\text { Levene's Test for Equality of } \\
\text { Variances }\end{array}$} & \multicolumn{7}{|c|}{ t-test for Equality of Means } \\
\hline & & \multirow[b]{2}{*}{$F$} & \multirow[b]{2}{*}{ Sig. } & \multirow[b]{2}{*}{$t$} & \multirow[b]{2}{*}{$d f$} & \multirow[b]{2}{*}{ Sig. (2-talled) } & \multirow[b]{2}{*}{$\begin{array}{c}\text { Mean } \\
\text { Difference }\end{array}$} & \multirow[b]{2}{*}{$\begin{array}{l}\text { Std. Error } \\
\text { Difference } \\
\end{array}$} & \multicolumn{2}{|c|}{$\begin{array}{l}95 \% \text { Confidence Interval of the } \\
\text { Difierence }\end{array}$} \\
\hline & & & & & & & & & Lower & Upper \\
\hline RU_semcl & $\begin{array}{l}\text { Equal variances } \\
\text { assumed }\end{array}$ & 37.501 & .000 & -3.666 & 150 & .000 & -1.22656 & .33460 & -1.88769 & .56542 \\
\hline & $\begin{array}{l}\text { Equal variances not } \\
\text { assumed }\end{array}$ & & & -3.218 & 72.793 & .002 & -1.22656 & .38112 & -1.98617 & .46694 \\
\hline
\end{tabular}

(B)-Fig.11

In this analysis there is a significant difference among the people from Rural and Urban community with inclination towards Semi-Classical Music Type as the 'P' value is lesser than 0.05

\section{CONCLUSION}

From the tables $\mathrm{C}$ and $\mathrm{E}$, we can conclude that there is no significant differences in average scores of Rural and Urban people for two music types : i.e. - Rap/Rock/Hip - Hop \& Bollywood music types. For rest, there is a significant difference in average score of rural and urban people 
Psychological Interpretation, Based On Statistical Analysis of Impact of Music on Rural and Urban People When Their Music Inclination Collides With Personality and Vice Versa - Comparative Study

for tables A, B, D, and F, which denotes the music types - Classical, Folk, Religious and Semi Classical.

ANOVA - 13 - 19 years Personality Traits

ANOVA is applied to test the significant difference in 5 personality traits in rural and urban people.

a) Anova applied on the five Personality Traits: Openness, Agreeableness, Consciousness, Extraversion and Neuroticism

Ho1: The average scores obtained under each personality trait are equal.

H1: At least two of the average scores are different

\begin{tabular}{|l|l|l|l|l|l|}
\hline $\begin{array}{l}\text { Personality } \\
-\quad \text { Urban } \\
\text { /Rural }\end{array}$ & Openness & Agreeableness & Consciousness & Extraversion & Neuroticism \\
\hline Mean & 5.4150 & 5.4450 & 5.5850 & 5.5500 & 2.3050 \\
\hline
\end{tabular}

(B)-Fig.12

\begin{tabular}{|c|c|c|c|c|c|}
\hline \multicolumn{6}{|c|}{ ANOVA } \\
\hline Group & Sum of Squares & df & Mean Square & $\mathbf{F}$ & $\mathbf{P}$ \\
\hline Between Groups & 1636 & 4 & 409 & 162.2369 & .000 \\
\hline Within Groups & 2508.4 & 995 & 2.521005 & & \\
\hline Total & 4144.4 & 999 & & & \\
\hline
\end{tabular}

(B)-Fig.13

Since ' $P$ ' value is lesser than 0.05 there is a significant difference in average score of ' 5 ' personality Traits.

b) Anova applied on the five personality traits of Rural People.

Ho2: The average scores obtained under each personality trait are equal for rural people.

H2: At least two of the average scores are different for rural people.

\begin{tabular}{|l|l|l|l|l|l|}
\hline $\begin{array}{l}\text { Personality } \\
\text { Rural }\end{array}$ & Openness & Agreeableness & Consciousness & Extraversion & Neuroticism \\
\hline Mean & 5.3762 & 5.5644 & 6.2574 & 5.6733 & 2.0297 \\
\hline
\end{tabular}

(B)-Fig.14

\begin{tabular}{|l|l|l|l|l|l|}
\hline \multicolumn{7}{|c|}{ ANOVA } \\
\hline Group & Sum of Squares & df & Mean Square & F & P \\
\hline Between Groups & 1142.832 & 4 & 285.7079 & 127.6656 & .000 \\
\hline Within Groups & 1118.97 & 500 & 2.237941 & & \\
\hline Total & 2261.802 & 504 & & & \\
\hline
\end{tabular}

(B)-Fig.15 
Psychological Interpretation, Based On Statistical Analysis of Impact of Music on Rural and Urban People When Their Music Inclination Collides With Personality and Vice Versa - Comparative Study

For Rural people ' $P$ ' value is lesser than 0.05 , therefore among rural people there is a significant difference found in ' 5 'personality traits

c) Anova applied on the five personality traits of Urban People.

Ho3: The average scores obtained under each personality trait are equal for urban people.

H3: At least two of the average scores are different for urban people.

\begin{tabular}{|l|l|l|l|l|l|}
\hline $\begin{array}{l}\text { Personality } \\
\text { - Urban }\end{array}$ & Openness & Agreeableness & Consciousness & Extraversion & Neuroticism \\
\hline Mean & 5.4545 & 5.3232 & 4.8990 & 5.4242 & 2.5859 \\
\hline
\end{tabular}

(B)-Fig.16

\begin{tabular}{|l|l|l|l|l|l|}
\hline \multicolumn{7}{|c|}{ ANOVA } \\
\hline Group & Sum of Squares & df & Mean Square & F & P \\
\hline Between Groups & 592.4646 & 4 & 148.1162 & 56.90549 & .000 \\
\hline Within Groups & 1275.394 & 490 & 2.602845 & & \\
\hline Total & 1867.859 & 494 & & & \\
\hline
\end{tabular}

(B)-Fig.17

For Urban people ' $P$ ' value is lesser than 0.05 , therefore among urban people there is a significant difference found in '5'personality traits

\section{CONCLUSION}

From the above tables we conclude that the average scores obtained for 5 personalities show significant differences. Moreover, this difference also exists if we separate rural and urban people.

ANOVA is applied to test the significant difference in 6 music types in rural and urban people.

a) Anova applied on 6 Music Types which are: Classical, Folk, Pop/Rap/Hiphop, Religious, Bollywood, Semi-Classical.

Ho1: The average scores obtained under each music type are equal.

H1: At least two of the average scores are different.

\begin{tabular}{|l|l|l|l|l|l|l|}
\hline $\begin{array}{l}\text { Music Types } \\
\text { Urban/Rural }\end{array}$ & Classical & Folk & Pop/Rap/HipHop & Religious & Bollywood & SemiClassical \\
\hline Mean & 2.3216 & 4.6600 & 4.5810 & 4.7940 & 6.9550 & 2.3568 \\
\hline
\end{tabular}

(B)-Fig.18

\begin{tabular}{|l|l|l|l|l|l|}
\hline \multicolumn{7}{|c|}{ ANOVA } \\
\hline Group & Sum of Squares & df & Mean Square & F & P \\
\hline Between Groups & 3020.672 & 5 & 604.1345 & 145.4379 & .000 \\
\hline Within Groups & 4552.675 & 1096 & 4.153901 & & \\
\hline Total & 7573.348 & 1101 & & & \\
\hline
\end{tabular}

(B)-Fig.19 
Psychological Interpretation, Based On Statistical Analysis of Impact of Music on Rural and Urban People When Their Music Inclination Collides With Personality and Vice Versa - Comparative Study

Since ' $P$ ' value is lesser than 0.05 there is a significant difference in average score of ' 6 ' music types.

b) Anova applied on the 6 music types on Rural People.

Ho2: The average scores obtained under each personality trait are equal for rural people.

H2: At least two of the average scores are different for rural people.

\begin{tabular}{|l|l|l|l|l|l|l|}
\hline $\begin{array}{l}\text { Music } \\
\text { Types } \\
\text { Rural }\end{array}$ & Classical & Folk & Pop/Rap/HipHop & Religious & Bollywood & $\begin{array}{l}\text { Semi } \\
\text { Classical }\end{array}$ \\
\hline Mean & 1.8515 & 6.3861 & 4.6364 & 5.7624 & 6.9109 & 1.8911 \\
\hline
\end{tabular}

(B)-Fig.20

\begin{tabular}{|l|l|l|l|l|l|}
\hline \multicolumn{7}{|c|}{ ANOVA } \\
\hline Group & Sum of Squares & df & Mean Square & F & P \\
\hline Between Groups & 2501.46 & 5 & 500.292 & 215.9433 & .000 \\
\hline Within Groups & 1181.555 & 510 & 2.316775 & & \\
\hline Total & 3683.016 & 515 & & & \\
\hline
\end{tabular}

(B)-Fig.21

For Rural people ' $P$ ' value is lesser than 0.05 , therefore among rural people there is a significant difference found in ' 6 'music types

c) Anova applied on the 6 music types on Urban People

Ho3: The average scores obtained under each personality trait are equal for urban people.

H3: At least two of the average scores are different for urban people.

\begin{tabular}{|l|l|l|l|l|l|l|}
\hline $\begin{array}{l}\text { Music } \\
\text { Types } \\
\text { Urban }\end{array}$ & Classical & Folk & Pop/Rap/HipHop & Religious & Bollywood & $\begin{array}{l}\text { Semi } \\
\text { Classical }\end{array}$ \\
\hline Mean & 3.0588 & 2.9608 & 5.0851 & 3.7600 & 7.000 & 3.1176 \\
\hline
\end{tabular}

(B)-Fig.22

\begin{tabular}{|l|l|l|l|l|l|}
\hline \multicolumn{7}{|c|}{ ANOVA } \\
\hline Group & Sum of Squares & df & Mean Square & F & P \\
\hline Between Groups & 650.1513 & 5 & 130.0303 & 29.94875 & .000 \\
\hline Within Groups & 1280.819 & 295 & 4.341759 & & \\
\hline Total & 1930.97 & 300 & & & \\
\hline
\end{tabular}

(B)-Fig.23

For Urban people ' $P$ ' value is lesser than 0.05 , therefore among urban people there is a significant difference found in ' 6 'music types 
Psychological Interpretation, Based On Statistical Analysis of Impact of Music on Rural and Urban

\section{CONCLUSION}

From the above table we could conclude, that the average scores obtained for 6 music types show significant difference, moreover this difference also exists if we separate urban and rural.

\section{STATISTICAL ANALYSIS - $t$ - TEST AND ANOVA (20 - 40 years)}

$\mathrm{T}$ - Test and ANOVA for the result and conclusion for our hypothesis, i.e. -

* To compare average score obtained by rural and urban people according to their personality traits and music inclinations for various age groups..

\section{t - TEST ANALYSIS FOR RURAL \& URBAN PERSONALITY: 20- 40 YEARS}

$\mathrm{T}$ - Test is applied to check the significant difference in the average score obtained for the rural and urban people for the different personality traits by applying Simple Random Analysis.

a) Openness:

Ho1: The average scores obtained by rural and urban community are equal for Openness personality.

H1: The averages are not equal for Openness personality.

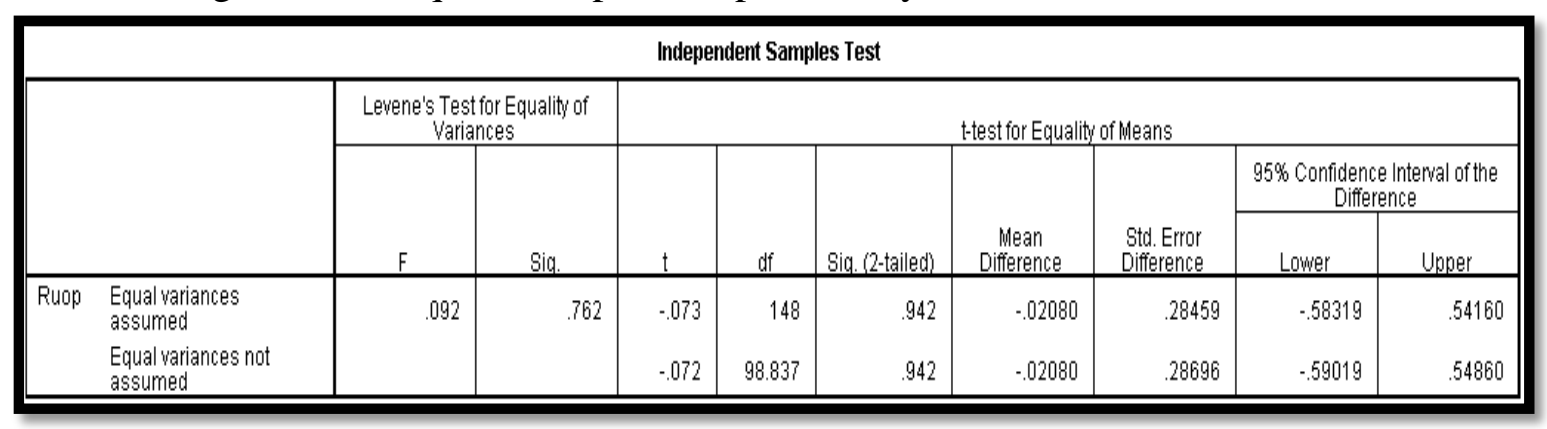

(B)-Fig.24

In this analysis there is a no significant difference among the people from Rural and Urban community with personality trait of Openness as the ' $P$ ' value is greater than 0.05

\section{b) Agreeableness:}

Ho2: The average scores obtained by rural and urban community are equal for Agreeableness personality.

H2: The averages are not equal for Agreeableness personality.

\begin{tabular}{|c|c|c|c|c|c|c|c|c|c|c|}
\hline \multicolumn{11}{|c|}{ Independent Samples Test } \\
\hline & & \multicolumn{2}{|c|}{$\begin{array}{l}\text { Levene's Test for Equality of } \\
\text { Variances }\end{array}$} & \multicolumn{7}{|c|}{ t-test for Equality of Means } \\
\hline & & \multirow[b]{2}{*}{$\mathrm{F}$} & \multirow[b]{2}{*}{ Sig. } & \multirow[b]{2}{*}{$t$} & \multirow[b]{2}{*}{$d f$} & \multirow[b]{2}{*}{ Sig. (2-tailed) } & \multirow[b]{2}{*}{$\begin{array}{l}\text { Mean } \\
\text { Difference }\end{array}$} & \multirow[b]{2}{*}{$\begin{array}{l}\text { Std. Error } \\
\text { Difference }\end{array}$} & \multicolumn{2}{|c|}{$\begin{array}{l}95 \% \text { Confidence Interval of the } \\
\text { Difference }\end{array}$} \\
\hline & & & & & & & & & Lower & Upper \\
\hline RU_agr & $\begin{array}{l}\text { Equal variances } \\
\text { assumed }\end{array}$ & 3.342 & .070 & -2.447 & 148 & .016 & -.62032 & .25353 & -1.12134 & -.11931 \\
\hline & $\begin{array}{l}\text { Equal variances not } \\
\text { assumed }\end{array}$ & & & & 118.233 & .011 & .62032 & .23937 & -1.09434 & -.14630 \\
\hline
\end{tabular}

(B)-Fig.25 
Psychological Interpretation, Based On Statistical Analysis of Impact of Music on Rural and Urban People When Their Music Inclination Collides With Personality and Vice Versa - Comparative Study

In this analysis there is a significant difference among the people from Rural and Urban community with Personality trait of Agreeableness as the ' $P$ ' value is lesser than 0.05

\section{c) Consciousness:}

Ho3: The average scores obtained by rural and urban community are equal for Consciousness personality.

H3: The averages are not equal for Consciousness personality.

\begin{tabular}{|c|c|c|c|c|c|c|c|c|c|c|}
\hline \multicolumn{11}{|c|}{ Independent Samples Test } \\
\hline & & \multicolumn{2}{|c|}{$\begin{array}{c}\text { Levene's Test for Equality of } \\
\text { Variances }\end{array}$} & \multicolumn{7}{|c|}{ t-test for Equality of Means } \\
\hline & & \multirow[b]{2}{*}{$\mathrm{F}$} & \multirow[b]{2}{*}{ Sig. } & \multirow[b]{2}{*}{$t$} & \multirow[b]{2}{*}{$d f$} & \multirow[b]{2}{*}{ Sig. (2-tailed) } & \multirow[b]{2}{*}{$\begin{array}{c}\text { Mean } \\
\text { Difiference }\end{array}$} & \multirow[b]{2}{*}{$\begin{array}{l}\text { Stdd. Error } \\
\text { Difference }\end{array}$} & \multicolumn{2}{|c|}{$\begin{array}{l}95 \% \text { Confidence Interval of the } \\
\text { Difference }\end{array}$} \\
\hline & & & & & & & & & Lower & Upper \\
\hline RU_con & $\begin{array}{l}\text { Equal variances } \\
\text { assumed }\end{array}$ & 2.234 & .137 & .331 & 148 & .741 & .09863 & .29797 & -49020 & .68746 \\
\hline & $\begin{array}{l}\text { Equal variances not } \\
\text { assumed }\end{array}$ & & & .315 & 88.399 & .754 & .09863 & .31323 & .52381 & $.7210 ?$ \\
\hline
\end{tabular}

(B)-Fig. 26

In this analysis there is no significant difference among the people from Rural and Urban community with Personality trait of Consciousness as the 'P' value is greater than 0.05

\section{d) Extraversion:}

Ho4: The average scores obtained by rural and urban community are equal for Extraversion personality.

H4: The averages are not equal for Extraversion personality.

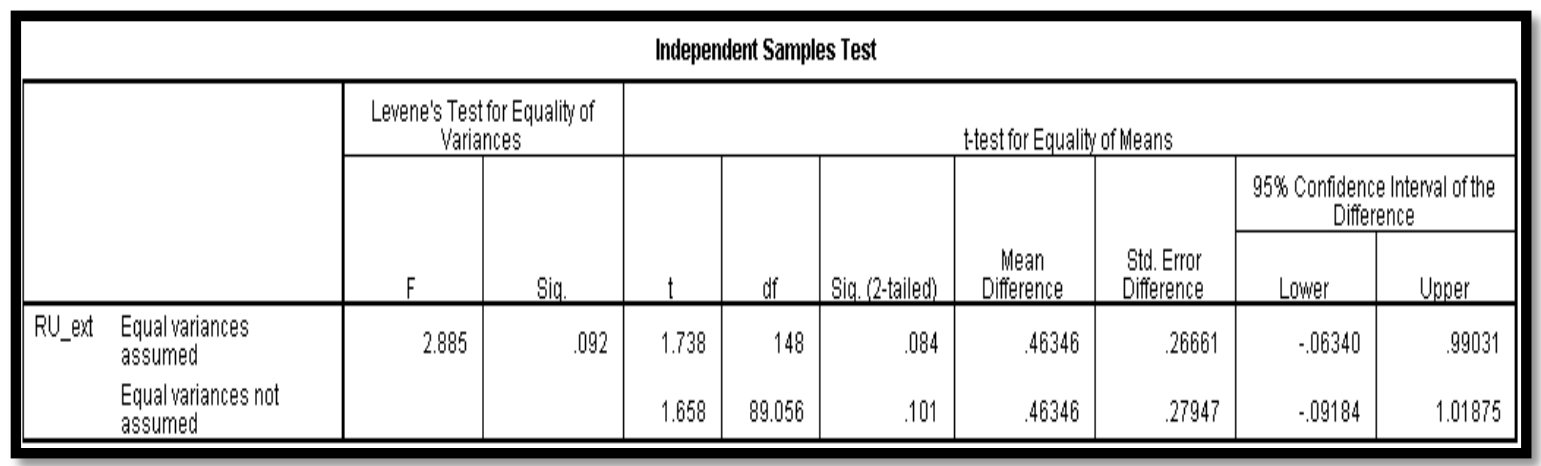

(B)-Fig.27

In this analysis there is no significant difference among the people from Rural and Urban community with Personality trait of Extraversion as the ' $P$ ' value is greater than 0.05

\section{e) Neuroticism:}

Ho5: The average scores obtained by rural and urban community are equal for Neuroticism personality.

H5: The averages are not equal for Neuroticism personality. 
Psychological Interpretation, Based On Statistical Analysis of Impact of Music on Rural and Urban People When Their Music Inclination Collides With Personality and Vice Versa - Comparative Study

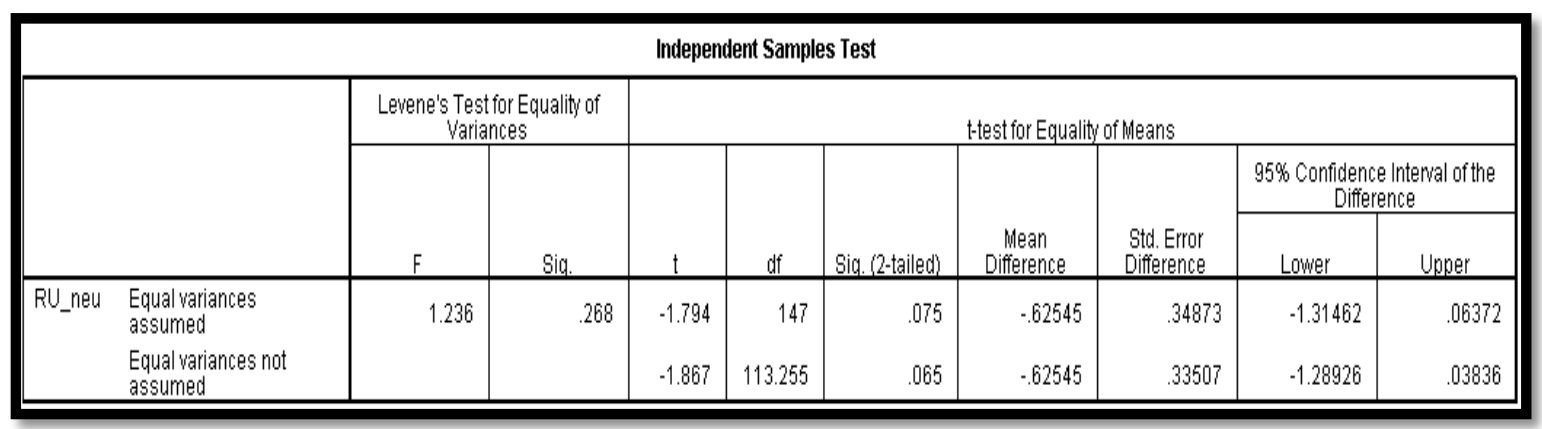

(B)-Fig. 28

In this analysis there is no significant difference among the people from Rural and Urban community with Personality trait of Neuroticism as the ' $P$ ' value is greater than 0.05 .

\section{CONCLUSION}

From the above tables we could conclude that there is insignificant difference in average scores of rural and urban people for 4 personality traits i.e. - Openness, Consciousness, Extraversion and Neuroticism. But for Agreeableness personality traits there is significance difference noticed from the average score that is obtained.

\section{t - TEST ANALYSIS FOR RURAL \& URBAN ON MUSIC TYPES: 20 - 40 YEARS}

a) Classical Music:

Ho1: The average scores obtained by rural and urban community are equal for Classical Music type.

H1: The averages are not equal for Classical Music type.

\begin{tabular}{|c|c|c|c|c|c|c|c|c|c|c|}
\hline \multicolumn{11}{|c|}{ Independent Samples Test } \\
\hline & & \multicolumn{2}{|c|}{$\begin{array}{c}\text { Levene's Test for Equality of } \\
\text { Variances }\end{array}$} & \multicolumn{7}{|c|}{ t-test for Equality of Means } \\
\hline & & \multirow[b]{2}{*}{$F$} & \multirow[b]{2}{*}{ Sig. } & \multirow[b]{2}{*}{$t$} & \multirow[b]{2}{*}{$\mathrm{df}$} & \multirow[b]{2}{*}{ Sig. (2-tailed) } & \multirow[b]{2}{*}{$\begin{array}{c}\text { Mean } \\
\text { Dififierence }\end{array}$} & \multirow[b]{2}{*}{$\begin{array}{l}\text { Std. Error } \\
\text { Difference }\end{array}$} & \multicolumn{2}{|c|}{$\begin{array}{l}95 \% \text { Confidence Interval of the } \\
\text { Difference }\end{array}$} \\
\hline & & & & & & & & & Lower & Upper \\
\hline RU_clas & $\begin{array}{l}\text { Equal variances } \\
\text { assumed }\end{array}$ & 31.727 & .000 & 9.369 & 198 & .000 & 2.69347 & .28749 & 2.12653 & 3.26041 \\
\hline & $\begin{array}{l}\text { Equal variances not } \\
\text { assumed }\end{array}$ & & & 9.395 & 185.672 & .000 & 2.69347 & .28669 & 2.12787 & 3.25907 \\
\hline
\end{tabular}

(B)-Fig.29

In this analysis there is a significant difference among the people from Rural and Urban community with inclination towards Classical Music Type as the 'P' value is lesser than 0 .05. b) Folk:

Ho2: The average scores obtained by rural and urban community are equal for Folk music type. H2: The averages are not equal for Folk music type. 
Psychological Interpretation, Based On Statistical Analysis of Impact of Music on Rural and Urban People When Their Music Inclination Collides With Personality and Vice Versa - Comparative Study

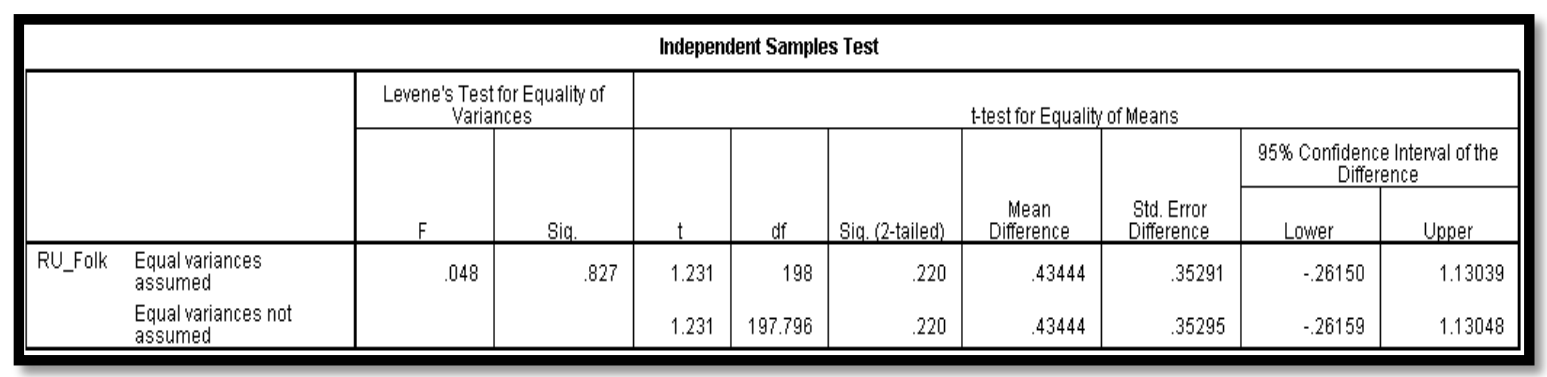

(B)-Fig.30

In this analysis there is no significant difference among the people from Rural and Urban community with inclination towards Folk Music Type as the ' $P$ ' value is greater than 0.05 .

c) Rap/Rock/Hip-hop:

Ho3: The average scores obtained by rural and urban community are equal for Rap/Rock/HipHop Music Type.

H3: The averages are not equal for Rap/Rock/Hip-Hop Music Type.

\begin{tabular}{|c|c|c|c|c|c|c|c|c|c|c|}
\hline \multicolumn{11}{|c|}{ Independent Samples Test } \\
\hline & & \multicolumn{2}{|c|}{$\begin{array}{c}\text { Levene's Test for Equality of } \\
\text { Variances }\end{array}$} & \multicolumn{7}{|c|}{ t-test for Equality of Means } \\
\hline & & \multirow[b]{2}{*}{$\mathrm{F}$} & \multirow[b]{2}{*}{ Sig. } & \multirow[b]{2}{*}{$t$} & \multirow[b]{2}{*}{ df } & \multirow[b]{2}{*}{ Siq. (2-tailed) } & \multirow[b]{2}{*}{$\begin{array}{c}\text { Mean } \\
\text { Difference }\end{array}$} & \multirow[b]{2}{*}{$\begin{array}{l}\text { Std. Error } \\
\text { Difierence }\end{array}$} & \multicolumn{2}{|c|}{$\begin{array}{l}95 \% \text { Confidence Interval of the } \\
\text { Difference }\end{array}$} \\
\hline & & & & & & & & & Lower & Upper \\
\hline RU_PoRaHi & $\begin{array}{l}\text { Equal variances } \\
\text { assumed }\end{array}$ & .925 & .338 & -5.494 & 157 & .000 & -1.82039 & .33136 & -2.47489 & -1.16590 \\
\hline & $\begin{array}{l}\text { Equal variances not } \\
\text { assumed }\end{array}$ & & & -5.390 & 126.255 & .000 & -1.82039 & .33771 & -2.48870 & -1.15209 \\
\hline
\end{tabular}

(B)-Fig.31

In this analysis there is a significant difference among the people from Rural and Urban community with inclination towards Rap/Rock/Hip-Hop Music Type as the 'P' value is lesser than 0.05 .

d) Religious:

Ho4: The average scores obtained by rural and urban community are equal for Religious Music type.

H4: The averages are not equal for Religious Music Type.

\begin{tabular}{|c|c|c|c|c|c|c|c|c|c|c|}
\hline \multicolumn{11}{|c|}{ Independent Samples Test } \\
\hline & & \multicolumn{2}{|c|}{$\begin{array}{c}\text { Levene's Test for Equality of } \\
\text { Variances }\end{array}$} & \multicolumn{7}{|c|}{ t-test for Equality of Means } \\
\hline & & \multirow[b]{2}{*}{$\mathrm{F}$} & \multirow[b]{2}{*}{ Sig. } & \multirow[b]{2}{*}{$t$} & \multirow[b]{2}{*}{$d f$} & \multirow[b]{2}{*}{ Siq. (2-tailed) } & \multirow[b]{2}{*}{$\begin{array}{c}\text { Mean } \\
\text { Difference }\end{array}$} & \multirow[b]{2}{*}{$\begin{array}{l}\text { Std. Error } \\
\text { Difference }\end{array}$} & \multicolumn{2}{|c|}{$\begin{array}{l}95 \% \text { Confidence Interval of the } \\
\text { Difference }\end{array}$} \\
\hline & & & & & & & & & Lower & Upper \\
\hline RU_Relig & $\begin{array}{l}\text { Equal variances } \\
\text { assumed }\end{array}$ & .074 & .785 & 1.578 & 197 & .116 & .49040 & .31078 & -.12248 & 1.10329 \\
\hline & $\begin{array}{l}\text { Equal variances not } \\
\text { assumed }\end{array}$ & & & 1.578 & 196.940 & .116 & .49040 & .31074 & -12240 & 1.10321 \\
\hline
\end{tabular}

(B)-Fig.32

In this analysis there is no significant difference among the people from Rural and Urban community with inclination towards Religious Music Type as the ' $P$ ' value is greater than 0.05 . 
Psychological Interpretation, Based On Statistical Analysis of Impact of Music on Rural and Urban People When Their Music Inclination Collides With Personality and Vice Versa - Comparative Study

e) Bollywood:

Ho5: The average scores obtained by rural and urban community are equal for Bollywood Music Type.

H5: The averages are not equal for Bollywood Music Type.

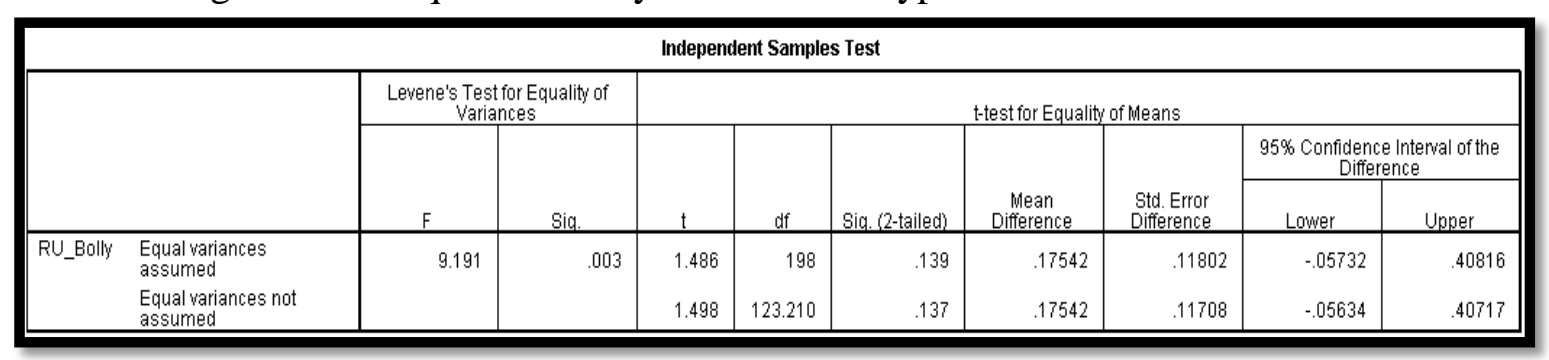

(B)-Fig.33

In this analysis there is no significant difference among the people from Rural and Urban community with inclination towards Bollywood Music Type as the ' $P$ ' value is greater than 0.05 .

f) Semi Classical:

Ho6: The average scores obtained by rural and urban community are equal for Semi-Classical Music Type.

H6: The averages are not equal for Semi-Classical Music Type

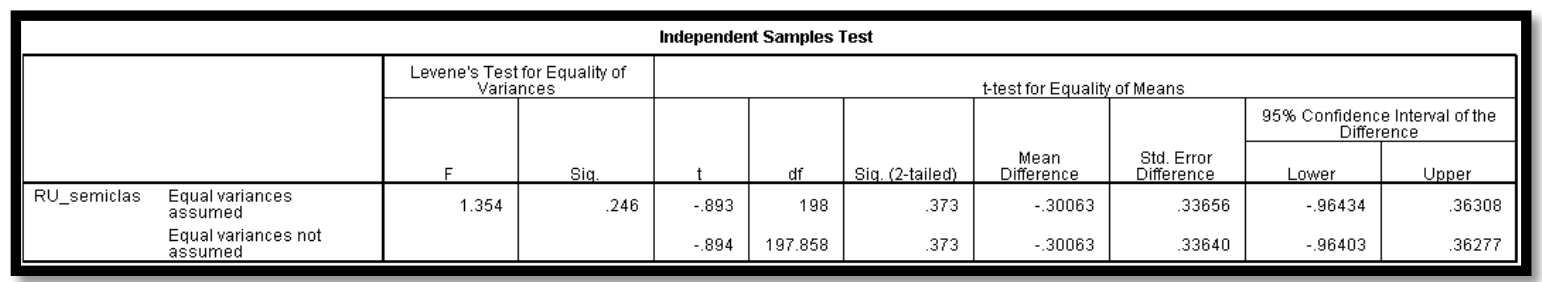

(B)-Fig.34

In this analysis there is no significant difference among the people from Rural and Urban community with inclination towards Semi Classical Music Type as the ' $P$ ' value is greater than 0.05 .

\section{CONCLUSION -}

From the tables $\mathrm{A}$ and $\mathrm{C}$ we could conclude that there is a significance difference in average scores of rural and urban people for two music types i.e. - Classical Music and Rap/Rock/ Hip Hop. For rest there is no significant differences noticed in average score of rural and urban people for - Folk, Religious, Bollywood, and Semi Classical Music Types.

ANOVA - 20 - 40 years Personality Traits

ANOVA is applied to test the significant difference in 5 personality traits in rural and urban people.

d) Anova applied on the five Personality Traits: Openness, Agreeableness, Consciousness, Extraversion and Neuroticism

Ho1: The average scores obtained under each personality trait are equal.

H1: At least two of the average scores are different 
Psychological Interpretation, Based On Statistical Analysis of Impact of Music on Rural and Urban People When Their Music Inclination Collides With Personality and Vice Versa - Comparative Study

\begin{tabular}{|l|l|l|l|l|l|}
\hline $\begin{array}{l}\text { Personality } \\
-\quad \text { Urban } \\
\text { /Rural }\end{array}$ & Openness & Agreeableness & Consciousness & Extraversion & Neuroticism \\
\hline Mean & 5.2150 & 5.6400 & 5.2550 & 5.9850 & 4.7800 \\
\hline
\end{tabular}

(B)-Fig.35

\begin{tabular}{|l|l|l|l|l|l|}
\hline \multicolumn{5}{|c|}{ ANOVA } \\
\hline Group & Sum of Squares & df & Mean Square & F & P \\
\hline Between Groups & 167.27 & 4 & 41.8175 & 13.92934 & .000 \\
\hline Within Groups & 2987.105 & 995 & 3.002116 & & \\
\hline Total & 3154.375 & 999 & & & \\
\hline
\end{tabular}

(B)-Fig.36

Since ' $P$ ' value is lesser than 0.05 there is a significant difference in average score of ' 5 ' personality Traits.

e) Anova applied on the five personality traits of Rural People.

Ho2: The average scores obtained under each personality trait are equal for rural people.

H2: At least two of the average scores are different for rural people.

\begin{tabular}{|l|l|l|l|l|l|}
\hline $\begin{array}{l}\text { Personality } \\
- \text { Rural }\end{array}$ & Openness & Agreeableness & Consciousness & Extraversion & Neuroticism \\
\hline Mean & 5.2929 & 5.5758 & 5.3535 & 6.0909 & 4.5556 \\
\hline
\end{tabular}

(B)-Fig.37

\begin{tabular}{|l|l|l|l|l|l|}
\hline \multicolumn{7}{|c|}{ ANOVA } \\
\hline Group & Sum of Squares & df & Mean Square & F & P \\
\hline Between Groups & 121.9192 & 4 & 30.4798 & 10.68365 & .000 \\
\hline Within Groups & 1397.939 & 490 & 2.852938 & & \\
\hline Total & 1519.859 & 494 & & & \\
\hline
\end{tabular}

(B)-Fig.38

For Rural people ' $P$ ' value is lesser than 0.05 , therefore among rural people there is a significant difference found in ' 5 'personality traits

f) Anova applied on the five personality traits of Urban People

Ho3: The average scores obtained under each personality trait are equal for urban people.

H3: At least two of the average scores are different for urban people.

\begin{tabular}{|l|l|l|l|l|l|}
\hline $\begin{array}{l}\text { Personality } \\
\text { - Urban }\end{array}$ & Openness & Agreeableness & Consciousness & Extraversion & Neuroticism \\
\hline Mean & 5.3137 & 6.1961 & 5.2549 & 5.6275 & 5.1765 \\
\hline
\end{tabular}

(B)-Fig.39 
Psychological Interpretation, Based On Statistical Analysis of Impact of Music on Rural and Urban People When Their Music Inclination Collides With Personality and Vice Versa - Comparative Study

\begin{tabular}{|l|l|l|l|l|l|}
\hline \multicolumn{6}{|c|}{ ANOVA } \\
\hline Group & Sum of Squares & df & Mean Square & F & P \\
\hline etween Groups & 35.663 & 4 & 8.916 & 3.087 & .017 \\
\hline Within Groups & 722.039 & 250 & 2.888 & & \\
\hline Total & 757.702 & 254 & & & \\
\hline
\end{tabular}

(B)-Fig.40

For Urban people ' $P$ ' value is lesser than 0.05 , therefore among urban people there is a significant difference found in '5'personality traits

\section{CONCLUSION -}

From the above tables we can conclude that the average scores obtained for 5 personalities show significant difference. More over this difference also exists if we separate rural and urban people.

\section{ANOVA - 20 - 40 years Music Types}

a) Anova applied on 6 Music Types which are: Classical, Folk, Pop/Rap/Hiphop, Religious, Bollywood, Semiclassical

Ho1: The average scores obtained under each music type are equal.

H1: At least two of the average scores are different.

\begin{tabular}{|l|l|l|l|l|l|l|}
\hline $\begin{array}{l}\text { Music Types } \\
\text { Urban/Rural }\end{array}$ & Classical & Folk & Pop/Rap/HipHop & Religious & Bollywood & SemiClassical \\
\hline Mean & 4.6600 & 4.7200 & 5.0255 & 4.7828 & 6.7700 & 2.9700 \\
\hline
\end{tabular}

(B)-Fig.41

\begin{tabular}{|l|l|l|l|l|l|}
\hline \multicolumn{6}{|c|}{ ANOVA } \\
\hline Group & Sum of Squares & df & Mean Square & F & P \\
\hline Between Groups & 1458.979 & 5 & 291.7957 & 61.85854 & .000 \\
\hline Within Groups & 5420 & 1149 & 4.717145 & & \\
\hline Total & 6878.978 & 1154 & & & \\
\hline
\end{tabular}

(B)-Fig.42

Since ' $P$ ' value is lesser than 0.05 there is a significant difference in average score of ' 6 ' music types.

b) Anova applied on the 6 music types on Rural People.

Ho2: The average scores obtained under each personality trait are equal for rural people.

H2: At least two of the average scores are different for rural people.

\begin{tabular}{|l|l|l|l|l|l|l|}
\hline $\begin{array}{l}\text { Music } \\
\text { Types } \\
\text { Rural }\end{array}$ & Classical & Folk & Pop/Rap/HipHop & Religious & Bollywood & SemiClassical \\
\hline Mean & 6.0202 & 4.9394 & 3.9375 & 5.0404 & 6.8586 & 2.8182 \\
\hline
\end{tabular}

(B)-Fig.43 
Psychological Interpretation, Based On Statistical Analysis of Impact of Music on Rural and Urban People When Their Music Inclination Collides With Personality and Vice Versa - Comparative Study

\begin{tabular}{|l|l|l|l|l|l|}
\hline \multicolumn{7}{|c|}{ ANOVA } & P \\
\hline Group & Sum of Squares & df & Mean Square & F & \\
\hline Between Groups & 989.0664 & 5 & 197.8133 & 49.58936 & .000 \\
\hline Within Groups & 2205.932 & 553 & 3.989027 & & \\
\hline Total & 3194.998 & 558 & & & \\
\hline
\end{tabular}

(B)-Fig.44

For Rural people ' $P$ ' value is lesser than 0.05 , therefore among rural people there is a significant difference found in '6'music types.

c) Anova applied on the 6 music types on Urban People

Ho3: The average scores obtained under each personality trait are equal for urban people.

H3: At least two of the average scores are different for urban people.

\begin{tabular}{|l|l|l|l|l|l|l|}
\hline $\begin{array}{l}\text { Music } \\
\text { Types } \\
\text { Urban }\end{array}$ & Classical & Folk & Pop/Rap/HipHop & Religious & Bollywood & SemiClassical \\
\hline Mean & 3.3267 & 4.5050 & 5.7579 & 4.5500 & 6.6832 & 3.1188 \\
\hline
\end{tabular}

(B)-Fig.45

\begin{tabular}{|l|l|l|l|l|l|}
\hline \multicolumn{7}{|c|}{ ANOVA } & P \\
\hline Group 2 & Sum of Squares & df & Mean Square & F & Pence \\
\hline Between Groups & 950.8857 & 5 & 190.1771 & 41.61314 & .000 \\
\hline Within Groups & 2710.083 & 593 & 4.570122 & & \\
\hline Total & 3660.968 & 598 & & & \\
\hline
\end{tabular}

(B)-Fig.46

For Urban people ' $P$ ' value is lesser than 0.05 , therefore among urban people there is $a$ significant difference found in '6'music types.

\section{CONCLUSION}

From the above table we can conclude that the average scores obtained for 6 music types show significant difference moreover, this difference also exists if we separate the rural and urban people.

STATISTICAL ANALYSIS - $\mathrm{t}$ - TEST AND ANOVA (40 - 75+ years)

$\mathrm{t}$ - Test and ANOVA for the result and conclusion for our hypothesis, i.e. -

* To compare average score obtained by rural and urban people according to their personality traits and music inclinations for various age groups.

Above mentioned objective and methods would remain the same for the analysis between the rest of the age groups i.e. 13 - 19years, 20 - 40 years and $40+-75+$ years. Each analysis would be explained individually through tabulation form. 
Psychological Interpretation, Based On Statistical Analysis of Impact of Music on Rural and Urban

\section{t - TEST ANALYSIS FOR RURAL \& URBAN PERSONALITY: 40+ - 75+ YEARS}

$\mathrm{t}$ - Test is applied to check the significant difference in the average score obtained for the rural and urban people for the different personality traits by applying Simple Random Analysis.

\section{F. Openness:}

Ho1: The average scores obtained by rural and urban community are equal for Openness personality.

H1: The averages are not equal for Openness personality.

\begin{tabular}{|c|c|c|c|c|c|c|c|c|c|c|}
\hline \multicolumn{11}{|c|}{ Independent Samples Test } \\
\hline & & \multicolumn{2}{|c|}{$\begin{array}{c}\text { Levene's Test for Equality of } \\
\text { Variances }\end{array}$} & \multicolumn{7}{|c|}{ t-test for Equality of Means } \\
\hline & & \multirow[b]{2}{*}{$\mathrm{F}$} & \multirow[b]{2}{*}{ Sig. } & \multirow[b]{2}{*}{$t$} & \multirow[b]{2}{*}{$d f$} & \multirow[b]{2}{*}{ Sig. (2-tailed) } & \multirow[b]{2}{*}{$\begin{array}{l}\text { Mean } \\
\text { Difference }\end{array}$} & \multirow[b]{2}{*}{$\begin{array}{l}\text { Std. Error } \\
\text { Difference }\end{array}$} & \multicolumn{2}{|c|}{$\begin{array}{l}95 \% \text { Confidence Interval of the } \\
\text { Difference }\end{array}$} \\
\hline & & & & & & & & & Lower & Upper \\
\hline RU_op & $\begin{array}{l}\text { Equal variances } \\
\text { assumed }\end{array}$ & 1.089 & .298 & -.193 & 198 & .847 & -.04000 & .20730 & -.44880 & .36880 \\
\hline & $\begin{array}{l}\text { Equal variances not } \\
\text { assumed }\end{array}$ & & & -.193 & 193.809 & .847 & -.04000 & .20730 & -.44886 & .36886 \\
\hline
\end{tabular}

\section{(B)-Fig.47}

In this analysis there is an insignificant difference among the people from Rural and Urban community with Personality trait of Openness as the ' $P$ ' value is greater than 0.05 .

\section{G. Agreeableness:}

Ho2: The average scores obtained by rural and urban community are equal for Agreeableness personality.

H2: The averages are not equal for Agreeableness personality.

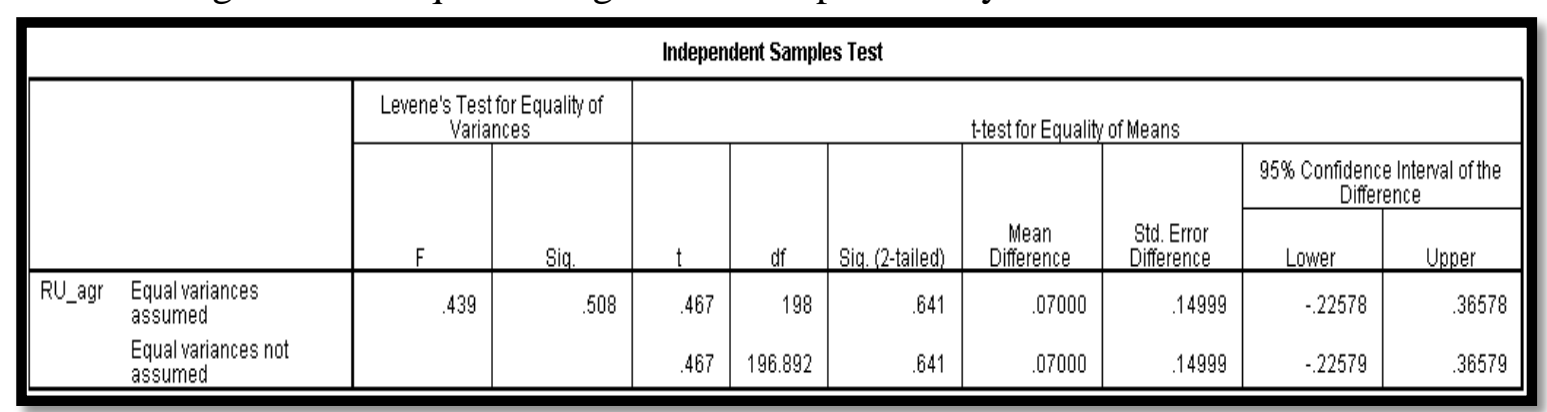

(B)-Fig.48

In this analysis there is an insignificant difference among the people from Rural and Urban community with Personality trait of Agreeableness as the ' $P$ ' value is greater than 0.05 .

\section{H. Consciousness:}

Ho3: The average scores obtained by rural and urban community are equal for Consciousness personality.

H3: The averages are not equal for Consciousness personality. 
Psychological Interpretation, Based On Statistical Analysis of Impact of Music on Rural and Urban People When Their Music Inclination Collides With Personality and Vice Versa - Comparative Study

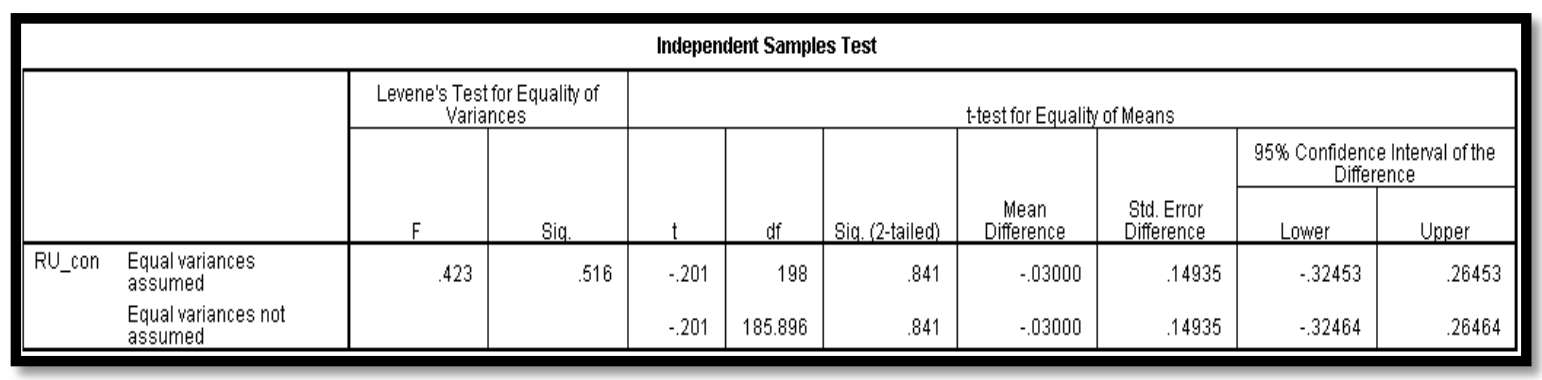

(B)-Fig.49

In this analysis there is an insignificant difference among the people from Rural and Urban community with Personality trait of Consciousness as the ' $P$ ' value is greater than 0.05 .

\section{Extraversion:}

Ho4: The average scores obtained by rural and urban community are equal for Extraversion personality.

H4: The averages are not equal for Extraversion personality.

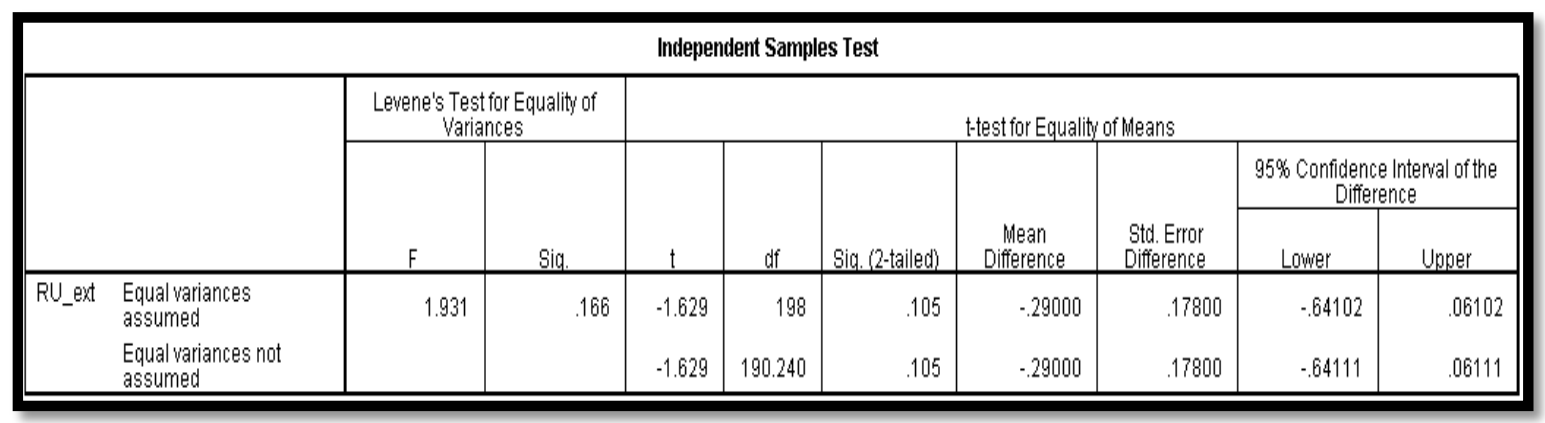

(B)-Fig.50

In this analysis there is an insignificant difference among the people from Rural and Urban community with Personality trait of Extraversion as the ' $P$ ' value is greater than 0.05 .

\section{J. Neuroticism:}

Ho5: The average scores obtained by rural and urban community are equal for Neuroticism personality.

H5: The averages are not equal for Neuroticism personality.

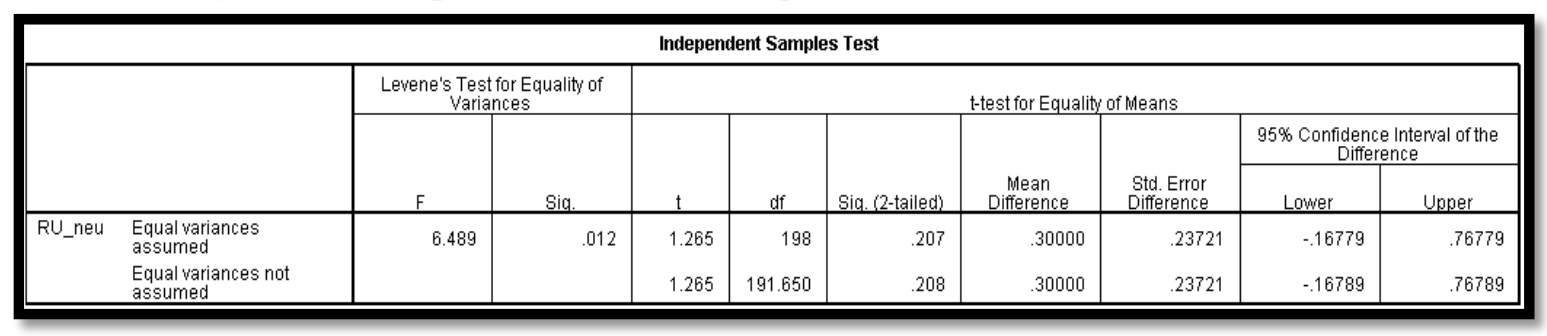

(B)-Fig.51

In this analysis there is an insignificant difference among the people from Rural and Urban community with Personality trait of Neuroticism as the ' $P$ ' value is greater than 0.05 . 
Psychological Interpretation, Based On Statistical Analysis of Impact of Music on Rural and Urban People When Their Music Inclination Collides With Personality and Vice Versa - Comparative Study

\section{CONCLUSION}

From the tables A, B, C, D and E we can conclude that there is no significant differences in the average score of rural and urban people for all the 5 personality traits.

\section{t - TEST ANALYSIS FOR RURAL \& URBAN ON MUSIC TYPES: 40+ - 75+ YEARS}

\section{a) Classical:}

Ho1: The average scores obtained by rural and urban community are equal for Classical Music type.

H1: The averages are not equal for Classical Music type.

\begin{tabular}{|c|c|c|c|c|c|c|c|c|c|c|}
\hline \multicolumn{11}{|c|}{ Independent Samples Test } \\
\hline & & \multicolumn{2}{|c|}{$\begin{array}{c}\text { Levene's Test for Equality of } \\
\text { Variances }\end{array}$} & \multicolumn{7}{|c|}{ t-test for Equality of Means } \\
\hline & & \multirow[b]{2}{*}{$\mathrm{F}$} & \multirow[b]{2}{*}{ Sig. } & \multirow[b]{2}{*}{$t$} & \multirow[b]{2}{*}{$\mathrm{df}$} & \multirow[b]{2}{*}{ Sia. (2-tailed) } & \multirow[b]{2}{*}{$\begin{array}{c}\text { Mean } \\
\text { Difference } \\
\end{array}$} & \multirow[b]{2}{*}{$\begin{array}{l}\text { Std. Error } \\
\text { Difference } \\
\end{array}$} & \multicolumn{2}{|c|}{$\begin{array}{l}95 \% \text { Confidence Interval of the } \\
\text { Difference }\end{array}$} \\
\hline & & & & & & & & & Lower & Upper \\
\hline RU_lls & $\begin{array}{l}\text { Equal variances } \\
\text { assumed }\end{array}$ & .297 & .586 & -8.573 & 198 & .000 & -2.64000 & .30794 & -3.24727 & -2.03273 \\
\hline & $\begin{array}{l}\text { Equal variances not } \\
\text { assumed }\end{array}$ & & & -8.573 & 197.996 & .000 & -2.64000 & .30794 & -3.24727 & -2.03273 \\
\hline
\end{tabular}

(B)-Fig.52

In this analysis there is a significant difference among the people from Rural and Urban community with inclination towards Classical Music Type as the 'P' value is lesser than 0.05 b) Folk:

Ho2: The average scores obtained by rural and urban community are equal for Folk music type. H2: The averages are not equal for Folk music type.

\begin{tabular}{|c|c|c|c|c|c|c|c|c|c|c|}
\hline \multicolumn{11}{|c|}{ Independent Samples Test } \\
\hline & & \multicolumn{2}{|c|}{$\begin{array}{c}\text { Levene's Test for Equality of } \\
\text { Variances }\end{array}$} & \multicolumn{7}{|c|}{ t-test for Equality of Means } \\
\hline & & \multirow[b]{2}{*}{$\mathrm{F}$} & \multirow[b]{2}{*}{ Sig. } & \multirow[b]{2}{*}{$t$} & \multirow[b]{2}{*}{$d f$} & \multirow[b]{2}{*}{ Sig. (2-tailed) } & \multirow[b]{2}{*}{$\begin{array}{c}\text { Mean } \\
\text { Difference }\end{array}$} & \multirow[b]{2}{*}{$\begin{array}{l}\text { Std. Error } \\
\text { Difference }\end{array}$} & \multicolumn{2}{|c|}{$\begin{array}{l}95 \% \text { Confidence Interval of the } \\
\text { Difference }\end{array}$} \\
\hline & & & & & & & & & Lower & Upper \\
\hline RU_folk & $\begin{array}{l}\text { Equal variances } \\
\text { assumed }\end{array}$ & 153.283 & .000 & 6.638 & 198 & .000 & 1.20000 & .18079 & .84348 & 1.55652 \\
\hline & $\begin{array}{l}\text { Equal variances not } \\
\text { assumed }\end{array}$ & & & 6.638 & 99.608 & .000 & 1.20000 & .18079 & .84130 & 1.55870 \\
\hline
\end{tabular}

(B)-Fig.53

In this analysis there is a significant difference among the people from Rural and Urban community with inclination towards Folk Music Type as the 'P' value is lesser than 0.05 c) Rap/Rock/Hip-hop:

Ho3: The average scores obtained by rural and urban community are equal for Rap/Rock/HipHop Music Type.

H3: The averages are not equal for Rap/Rock/Hip-Hop Music Type. 
Psychological Interpretation, Based On Statistical Analysis of Impact of Music on Rural and Urban People When Their Music Inclination Collides With Personality and Vice Versa - Comparative Study

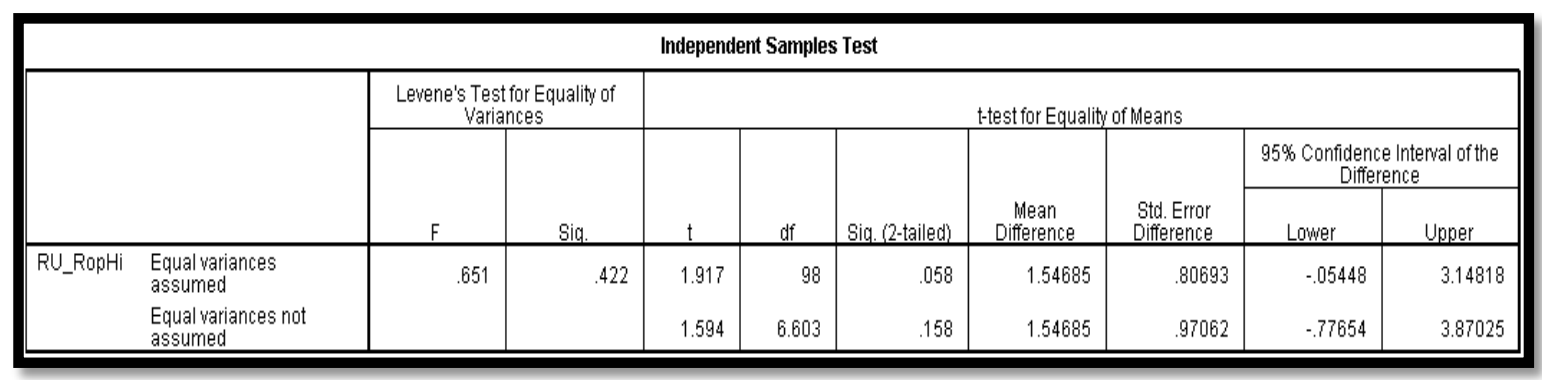

(B)-Fig.54

In this analysis there is a significant difference among the people from Rural and Urban community with inclination towards Rap/Rock/Hip-Hop Music Type as the 'P' value is lesser than 0.05 .

d) Religious:

Ho4: The average scores obtained by rural and urban community are equal for Religious Music type.

H4: The averages are not equal for Religious Music Type.

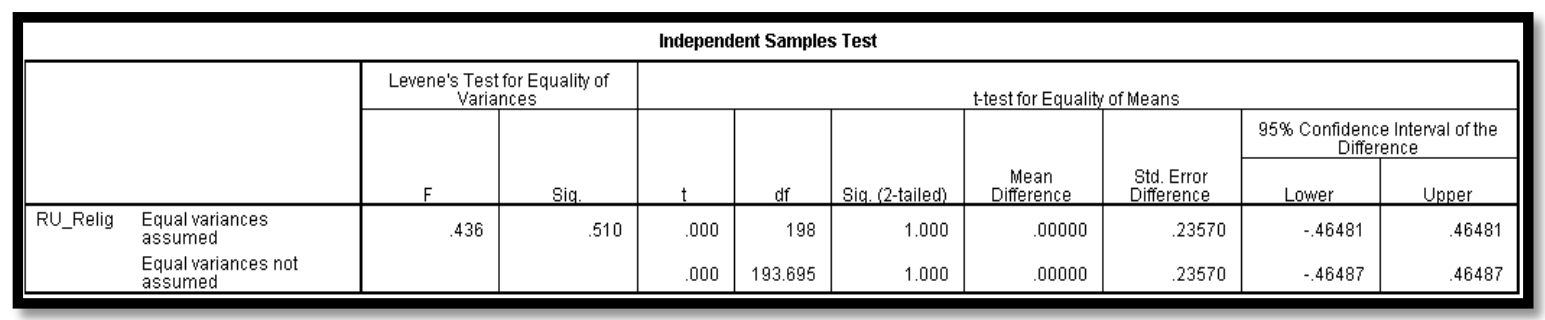

(B)-Fig.55

In this analysis there is no significant difference among the people from Rural and Urban community with inclination towards Religious Music Type as the ' $P$ ' value is greater than 0.05 e) Bollywood:

Ho5: The average scores obtained by rural and urban community are equal for Bollywood Music Type.

H5: The averages are not equal for Bollywood Music Type.

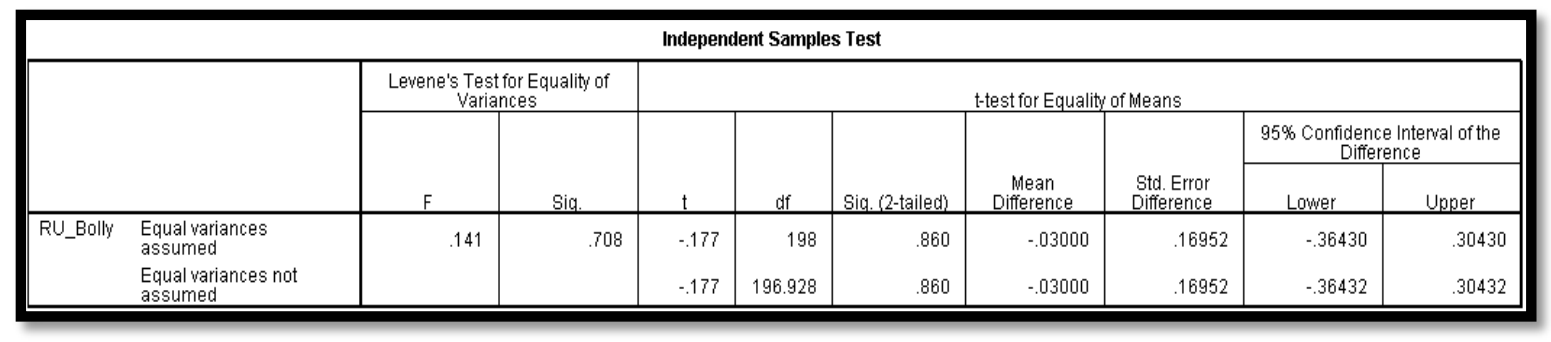

(B)-Fig.56

In this analysis there is no significant difference among the people from Rural and Urban community with inclination towards Bollywood Music Type as the ' $P$ ' value is greater than 0.05 
Psychological Interpretation, Based On Statistical Analysis of Impact of Music on Rural and Urban People When Their Music Inclination Collides With Personality and Vice Versa - Comparative Study

\section{f) Semi Classical:}

Ho6: The average scores obtained by rural and urban community are equal for Semi-Classical Music Type.

H6: The averages are not equal for Semi-Classical Music Type.

\begin{tabular}{|c|c|c|c|c|c|c|c|c|c|c|}
\hline \multicolumn{11}{|c|}{ Independent Samples Test } \\
\hline & & \multicolumn{2}{|c|}{$\begin{array}{c}\text { Levene's Test for Equality of } \\
\text { Variances }\end{array}$} & \multicolumn{7}{|c|}{ t-test for Equality of Means } \\
\hline & & \multirow[b]{2}{*}{$\mathrm{F}$} & \multirow[b]{2}{*}{ Siq. } & \multirow[b]{2}{*}{$t$} & \multirow[b]{2}{*}{ df } & \multirow[b]{2}{*}{ Siq. (2-tailed) } & \multirow[b]{2}{*}{$\begin{array}{c}\text { Mean } \\
\text { Difference }\end{array}$} & \multirow[b]{2}{*}{$\begin{array}{l}\text { Std. Error } \\
\text { Difference }\end{array}$} & \multicolumn{2}{|c|}{$\begin{array}{l}95 \% \text { Confidence Interval of the } \\
\text { Difference }\end{array}$} \\
\hline & & & & & & & & & Lower & Unper \\
\hline RU_semcls & $\begin{array}{l}\text { Equal variances } \\
\text { assumed }\end{array}$ & .317 & .574 & -9.082 & 198 & .000 & -2.76000 & .30391 & -3.35932 & -2.16068 \\
\hline & $\begin{array}{l}\text { Equal variances not } \\
\text { assumed }\end{array}$ & & & -9.082 & 197.994 & .000 & -2.76000 & .30391 & -3.35932 & -2.16068 \\
\hline
\end{tabular}

(B)-Fig.57

In this analysis there is significant difference among the people from Rural and Urban community with inclination towards Semi Classical Music Type as the ' $P$ ' value is lesser than 0.05

\section{CONCLUSION}

From the table $\mathrm{D}$ and $\mathrm{E}$ we can conclude that there is no significance difference in average score of rural and urban people for music types - Religious and Bollywood. For rest there is a significant difference notice in average score of rural and urban people for table - A, B, C, F. i.e. Classical, Folk, Rap/Rock/ Hip-Hop, and Semi - Classical music type.

ANOVA - 40+ - 75+ years Personality Traits

ANOVA is applied to test the significant difference in 5 personality traits in rural and urban people.

a) Anova applied on the five Personality Traits: Openness, Agreeableness, Consciousness, Extraversion and Neuroticism

Ho1: The average scores obtained under each personality trait are equal.

H1: At least two of the average scores are different

\begin{tabular}{|l|l|l|l|l|l|}
\hline $\begin{array}{l}\text { Personality } \\
-\quad \text { Urban } \\
\text { /Rural }\end{array}$ & Openness & Agreeableness & Consciousness & Extraversion & Neuroticism \\
\hline Mean & 5.8200 & 6.2650 & 6.2360 & 6.0750 & 5.8900 \\
\hline
\end{tabular}

\begin{tabular}{|l|l|l|l|l|l|}
\hline \multicolumn{7}{|c|}{ (B)-Fig.58 } \\
\hline Group & Sum of Squares & df & Mean Square & F & P \\
\hline Between Groups & 31.21529 & 4 & 7.803822 & 4.353803 & .002 \\
\hline Within Groups & 1744.02 & 973 & 1.792415 & & \\
\hline Total & 1775.235 & 977 & & & \\
\hline
\end{tabular}

(B)-Fig.59 
Psychological Interpretation, Based On Statistical Analysis of Impact of Music on Rural and Urban People When Their Music Inclination Collides With Personality and Vice Versa - Comparative Study

Since ' $P$ ' value is lesser than 0.05 there is a significant difference in average score of ' 5 ' personality Traits.

b) Anova applied on the five personality traits of Rural People.

Ho2: The average scores obtained under each personality trait are equal for rural people.

H2: At least two of the average scores are different for rural people.

\begin{tabular}{|l|l|l|l|l|l|}
\hline $\begin{array}{l}\text { Personality } \\
\text { - Rural }\end{array}$ & Openness & Agreeableness & Consciousness & Extraversion & Neuroticism \\
\hline Mean & 5.8000 & 6.3000 & 6.2100 & 5.9300 & 6.0400 \\
\hline
\end{tabular}

(B)-Fig.60

\begin{tabular}{|l|l|l|l|l|l|}
\hline \multicolumn{7}{|c|}{ ANOVA } \\
\hline Group 1 & Sum of Squares & df & Mean Square & F & P \\
\hline Between Groups & 16.492 & 4 & 4.123 & 2.262772 & .061 \\
\hline Within Groups & 901.94 & 495 & 1.822101 & & \\
\hline Total & 918.432 & 499 & & & \\
\hline
\end{tabular}

(B)-Fig.61

For Rural people ' $P$ ' value is greater than 0.05 , therefore among rural people there is no significant difference found in '5'personality traits

c) Anova applied on the five personality traits of Urban People

Ho3: The average scores obtained under each personality trait are equal for urban people.

H3: At least two of the average scores are different for urban people

\begin{tabular}{|l|l|l|l|l|l|}
\hline $\begin{array}{l}\text { Personality } \\
\text { - Urban }\end{array}$ & Openness & Agreeableness & Consciousness & Extraversion & Neuroticism \\
\hline Mean & 5.8400 & 6.2300 & 6.2400 & 6.2200 & 5.7400 \\
\hline
\end{tabular}

(B)-Fig.62

\begin{tabular}{|l|l|l|l|l|l|}
\hline \multicolumn{7}{|c|}{ ANOVA } & P \\
\hline Group 2 & Sum of Squares & Df & Mean Square & F & \\
\hline Between Groups & 23.752 & 4 & 5.938 & 3.508409 & .008 \\
\hline Within Groups & 837.79 & 495 & 1.692505 & & \\
\hline Total & 861.542 & 499 & & & \\
\hline
\end{tabular}

(B)-Fig.63

For Urban people ' $P$ ' value is lesser than 0.05 , therefore among urban people there is a significant difference found in ' 5 'personality traits.

\section{CONCLUSION}

From the above table we can conclude that the average score obtained for 5 personalities show significant differences. Moreover this significant difference exits if we separate Urban and rural person but there is insignificant difference in the average score obtained for the rural and urban people. 
Psychological Interpretation, Based On Statistical Analysis of Impact of Music on Rural and Urban People When Their Music Inclination Collides With Personality and Vice Versa - Comparative Study

ANOVA - 40+ - 75+ years Music Types

d) Anova applied on 6 Music Types which are: Classical, Folk, Pop/Rap/Hiphop, Religious, Bollywood, Semiclassical

Ho1: The average scores obtained under each music type are equal.

H1: At least two of the average scores are different.

\begin{tabular}{|l|l|l|l|l|l|l|}
\hline $\begin{array}{l}\text { Music Types } \\
\text { Urban/Rural }\end{array}$ & Classical & Folk & Pop/Rap/HipHop & Religious & Bollywood & SemiClassical \\
\hline Mean & 3.9400 & 6.3900 & 2.9900 & 6.0000 & 6.6650 & 3.9400 \\
\hline
\end{tabular}

(B)-Fig.64

\begin{tabular}{|l|l|l|l|l|l|}
\hline \multicolumn{7}{|c|}{ ANOVA } \\
\hline Group & Sum of Squares & df & Mean Square & F & P \\
\hline Between Groups & 1962.864 & 5 & 392.5728 & 101.2032 & .000 \\
\hline Within Groups & 4243.685 & 1094 & 3.879054 & & \\
\hline Total & 6206.549 & 1099 & & & \\
\hline
\end{tabular}

(B)-Fig.65

Since ' $P$ ' value is lesser than 0.05 there is a significant difference in average score of ' 6 ' music types.

e) Anova applied on the 6 music types on Rural Music

Ho2: The average scores obtained under each personality trait are equal for rural people.

H2: At least two of the average scores are different for rural people.

\begin{tabular}{|l|l|l|l|l|l|l|}
\hline $\begin{array}{l}\text { Music } \\
\text { Types } \\
\text { Rural }\end{array}$ & Classical & Folk & Pop/Rap/HipHop & Religious & Bollywood & SemiClassical \\
\hline Mean & 2.6200 & 6.9900 & 4.4286 & 6.0000 & 6.6500 & 2.5600 \\
\hline
\end{tabular}

(B)-Fig.66

\begin{tabular}{|c|c|c|c|c|c|}
\hline \multicolumn{6}{|c|}{ ANOVA } \\
\hline Group 1 & Sum of Squares & Df & Mean Square & $\mathbf{F}$ & $\mathbf{P}$ \\
\hline Between Groups & 1931.391 & 5 & 386.2782 & 143.1767 & .000 \\
\hline Within Groups & 1351.654 & 501 & 2.697913 & & \\
\hline Total & 3283.045 & 506 & & & \\
\hline
\end{tabular}

(B)-Fig.67

For Rural people ' $P$ ' value is lesser than 0.05 , therefore among rural people there is a significant difference found in '6'music types.

f) Anova applied on the 6 music types on Urban Music

Ho3: The average scores obtained under each personality trait are equal for urban people.

H3: At least two of the average scores are different for urban people. 
Psychological Interpretation, Based On Statistical Analysis of Impact of Music on Rural and Urban People When Their Music Inclination Collides With Personality and Vice Versa - Comparative Study

\begin{tabular}{|l|l|l|l|l|l|l|}
\hline $\begin{array}{l}\text { Music } \\
\text { Types } \\
\text { Urban }\end{array}$ & Classical & Folk & Pop/Rap/HipHop & Religious & Bollywood & SemiClassical \\
\hline Mean & 5.2600 & 5.7900 & 2.8817 & 6.0000 & 6.6800 & 5.3200 \\
\hline
\end{tabular}

(B)-Fig.68

\begin{tabular}{|l|l|l|l|l|l|}
\hline \multicolumn{7}{|c|}{ ANOVA } \\
\hline Group 2 & Sum of Squares & df & Mean Square & F & P \\
\hline Between Groups & 805.9932 & 5 & 161.1986 & 45.60066 & .000 \\
\hline Within Groups & 2075.049 & 587 & 3.535007 & & \\
\hline Total & 2881.042 & 592 & & & \\
\hline
\end{tabular}

(B)-Fig.69

For Urban people ' $P$ ' value is lesser than 0.05 , therefore among urban people there is a significant difference found in ' 6 'music types

\section{CONCLUSION}

From the above tables we could conclude that the average score obtained for 6 music types shows significant differences where as their significant difference is also exists if we separate urban and rural people.

\section{REFERENCES}

Adorno, T.W. Frenkel - Brunswik, E., Levinson, D.J., \& Sansford, R.N. (1950). The Authoritarian Personality. New York, NY

Allport, G.W. (1936). Trait names: A psycho lexical study. Psychological Monographs 47: 211.

Allport, G.W. (1937). Personaity: A psychological interpretation. New York: Holt, Rinehart \& Winston.

Atkinson, Rita, L.; Richard C. Atkinson; Edward E. Smith; Daryl J. Bem; Susan Nolenhoeksema. (2000). Hilgard's Introduction to Psychology (13 ed.). Orlando, Florida: Harcourt College, Publishers, p. 437.

M.D. Calvocoressi. (1925). Musical Taste and How to form it. Oxford University Press, H. Milford.

Misra .S. and Shastr .I. (2014). Paper published in International Journal of Research in Humanities, Arts and Literature by Ohio University Publication titled: ENCROACHMENT OF MUSIC ON LONELINESS IN WIDOWED AND BACHELORS. ISSN: 2321-8878

Misra .S. and Shastr .I. (2014).Paper published in International Journal of Education and Psychological Research (IJEPR) titled: PSYCHOLOGY OF MUSIC IN EDUCATING STUDENTS FROM PRIMARY TO SECONDARY LEVEL THROUGH TECHNOLOGY : ISSN: 2279-0179 
Psychological Interpretation, Based On Statistical Analysis of Impact of Music on Rural and Urban

Misra .S. and Shastr .I. Paper published in International Journal of Research and Scientific Innovation (IJRSI) titled : EMPIRICAL STUDY: IMPACT OF MUSIC ON PERSONALITY AND BEHAVIOUR OF CHILDREN: ISSN: 2321-2705.

Misra .S. and Shastr .I.(2014).Paper published in Asian Journal Of Multidisciplinary Studies titled: THE ROLE OF MUSIC IN PSYCHOLOGICAL AND EMOTIONAL DEVELOPMENT : ISSN: 2321-8819

Misra .S. and Shastr .I.(2014).Paper published in Journal of International Academic Research for Multidisciplinary (JIARM) titled : REFLECTION OF MUSIC ON THE PERSONALITY FROM INFANCY TO CHILDHOOD :ISSN: 2320 -5083

P. Richard and M. Gary. (2011). The science \& Psychology of music performance: Creative strategies for teaching and learning. Oxford Scholarship Online.

Shveata Misra, Ina Shastri. Perceptual Experience and Auditory Inclination of Music According to the Sexuality. Psychology and Behavioral Sciences. Vol.5, No. , 2016, pp-7-11. Doi: 10.11648/j.pbs.20160501.12

How to cite this article: S Misra, I Shastri (2016), Psychological Interpretation, Based On Statistical Analysis of Impact of Music on Rural and Urban People When Their Music Inclination Collides With Personality and Vice Versa - Comparative Study, International Journal of Indian Psychology, Volume 3, Issue 3, No. 7, DIP: 18.01.129/20160303, ISBN: 978-1-365$12175-3$ 